\title{
Palaeobiology of Mesoproterozoic Salkhan Limestone, Semri Group, Rohtas, Bihar, India: Systematics and significance
}

\author{
MUKUND SHARMA \\ Birbal Sahni Institute of Palaeobotany, 53 University Road, Lucknow 226 007, India. \\ e-mail: sharmamukund1@rediffmail.com
}

\begin{abstract}
Mesoproterozoic ( 1600 Ma old) Salkhan Limestone (Semri Group) of the Vindhyan Supergroup, exposed in Rohtas district of Bihar, India, preserves an abundant and varied ancient microbial assemblage. These microfossils are recorded in three distinctly occurring cherts viz., bedded chert, stromatolitic chert and cherty stromatolites. 27 morphoforms belonging to 14 genera and 21 species have been recognized. Six unnamed forms are also described.

The microbial assemblage, almost exclusively composed of the remnants of cyanobacteria, is dominated by entophysalidacean members and short trichomes and can be termed as 'typical Mesoproterozoic microbiotas'. The assemblage includes characteristic mat-forming scytonematacean and entophysalidacean cyanobacteria. Eoentophysalis is the dominant organism in the assemblage. Ellipsoidal akinetes of nostocalean cyanobacteria (Archaeollipsoides) and spherical unicells also occur; both are distinct from mat forming assemblage, allochthonous and possibly planktic. Cooccurrence of the microbiotas and precipitates is related to the depositional environment of the Mesoproterozoic tidal flats with high carbonate saturation.
\end{abstract}

\section{Introduction}

A number of publications have appeared in past years on the palaeobiological remains of the Proterozoic Vindhyan Supergroup, viz., the microfossils (Kumar and Srivastava 1992a, b, 1995; Anbarasu 2001), carbonaceous megaremains (Kumar 1995, 2001; Rai and Guatam 1998; Azmi 1998), and trace fossils (Sarkar et al 1996; Seilacher et al 1998; Chakraborty 2001) reflecting the renewed attempts to understand the palaeobiology of the basin. The interest and importance lie in tracing the antiquity of the life forms and the age of the fossil bearing Vindhyan sediments that have long been an enigma (see Venkatachala et al 1996; Sharma 2003 for comprehensive reviews). The recent radiometric datings of various horizons of the Semri Group (Kumar et al 2001; Rasmussen et al 2002; Ray et al 2002, 2003; Sarangi et al 2004) have thrown a challenge in the understanding of the evolution of life in Vindhyans.

The Vindhyan Supergroup is well exposed in central India (figure 1). There are a few reports of palaeobiological remains from the easternmost part of the basin (Beer 1919; Maithy 1989; Azmi 1998). Except a brief account of microfossils (Venkatachala et al 1990) no detailed systematic account of the microfossils is available from the eastern most fringe of the basin.

In the present paper diverse Mesoproterozoic microbial assemblage recorded from the Salkhan Limestone of the Vindhyan basin exposed in the Rohtas District, Bihar is being reported (see figures 1 and 2). Palaeoenvironmental interpretation of the assemblage and significance of the microfossils have also been discussed.

Keywords. Palaeobiology; cyanobactetria; microfossils; Semri Group; Vindhyan Supergroup; India. 


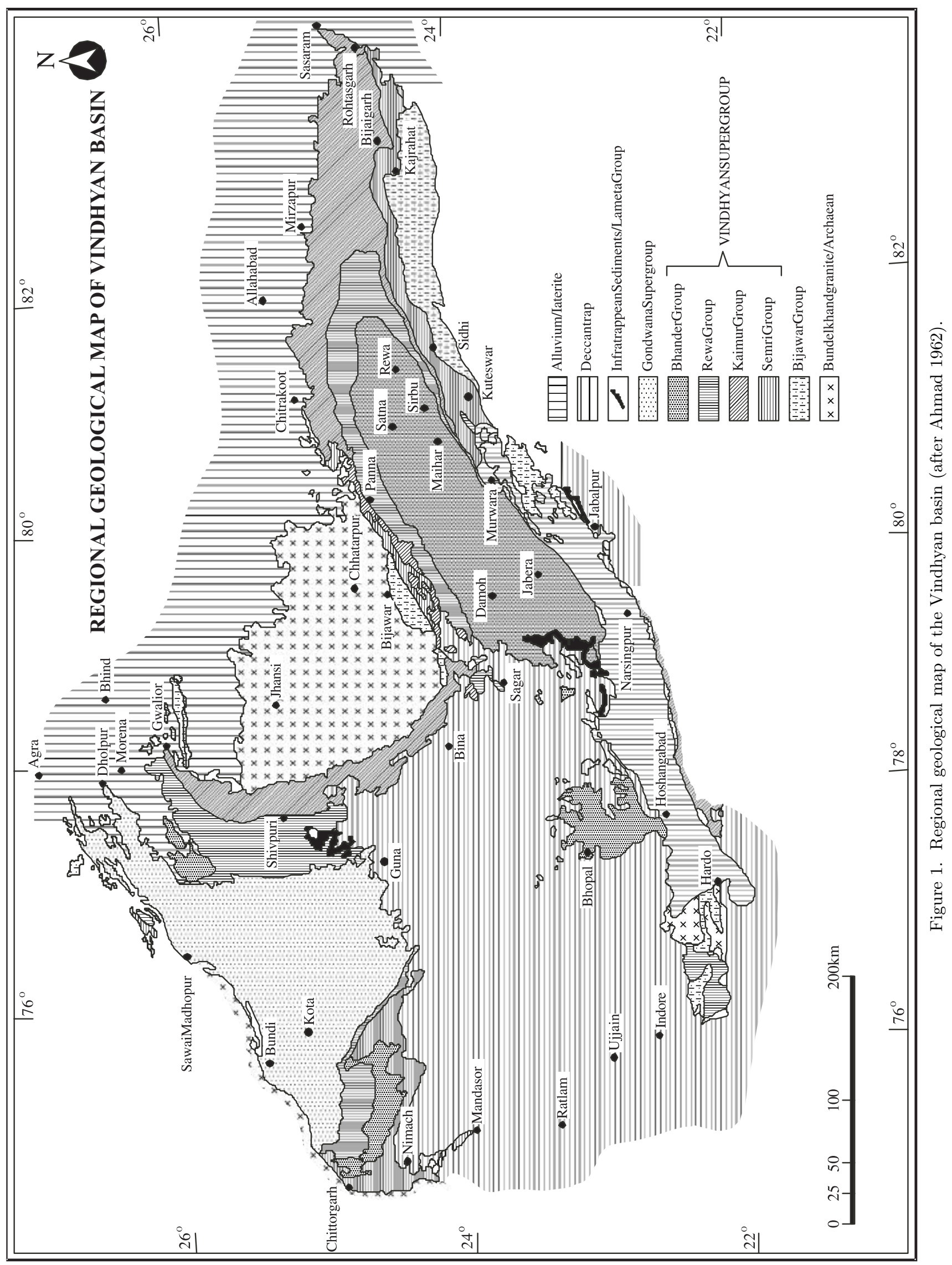




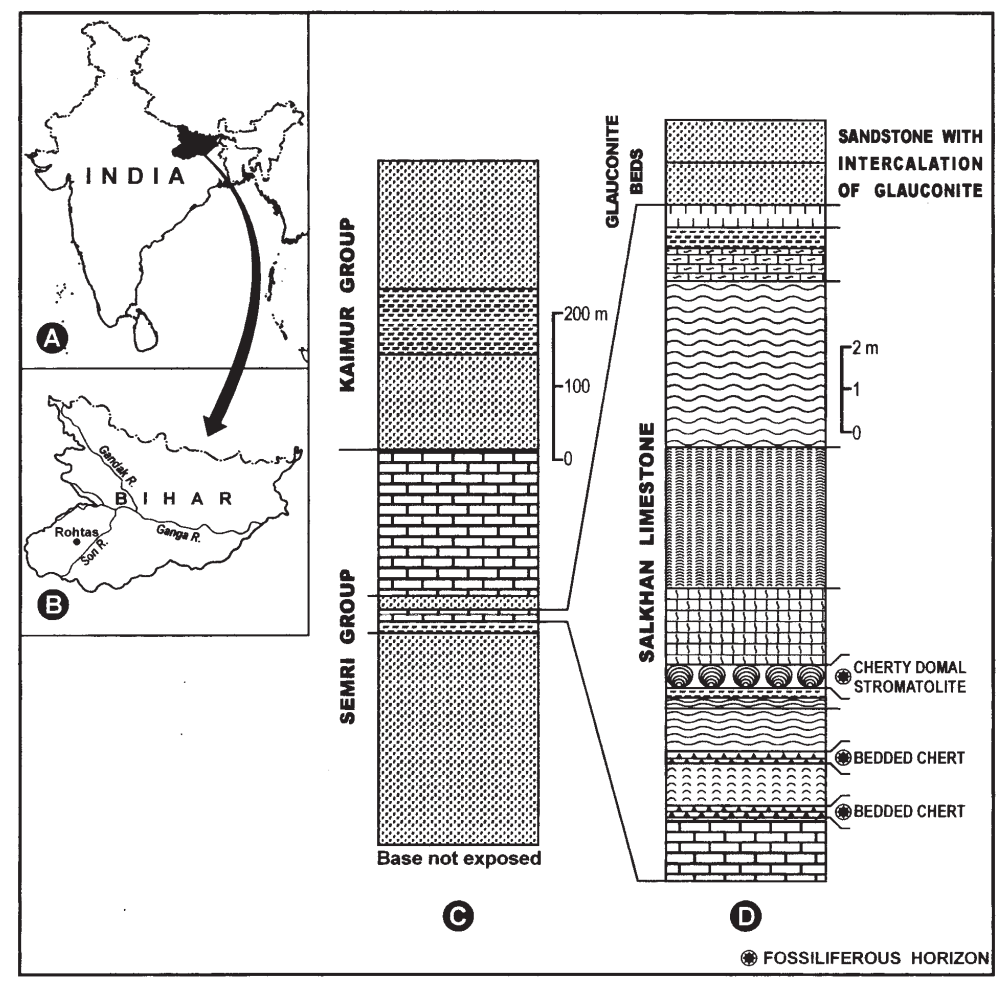

Figure 2. Geographic and stratigraphic location of fossiliferous cherts from the Salkhan Limestone. (A) Index map of India with position of Bihar state. (B) Outline map of Bihar showing position of Rohtas District where microfossiliferous outcrops of the Salkhan Limestone occur. (C) Generalized stratigraphic column of the Semri and Kaimur Groups exposed in Rohtas. (D) Detailed litholog of Salkhan Limestone, showing location of fossiliferous horizons (after Sharma and Sergeev 2004).

Table 1. Generalized lithostratigraphic succession of Vindhyan Supergroup (modified after Auden 1933 and Bhattacharyya 1996).

\begin{tabular}{|c|c|c|c|}
\hline & & After Auden (1933) & After Bhattacharyya (1996) \\
\hline \multirow{17}{*}{ 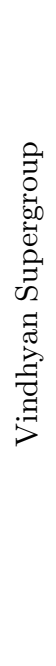 } & \multirow{6}{*}{ 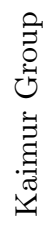 } & Dhandraul quartzite & Dhandraul Sandstone \\
\hline & & Scarp sandstone and shale & Mangesar Formation \\
\hline & & Bijaigarh Shale & Bijaigarh Shale \\
\hline & & Upper quartzite and sandstone & Ghaghar Sandstone \\
\hline & & Susnai Breccia & Susnai Breccia \\
\hline & & Lower quartzite and shale & Sasaram Formation \\
\hline & & - - - - - - - Unconfo & $-\ldots-\ldots-\ldots$ \\
\hline & & Nodular limestone and shale & Bhagwar Shale \\
\hline & & Banded shale and limestone & \\
\hline & 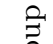 & Nodular limestone & Rohtasgarh Limestone \\
\hline & O & Glauconite beds & Rampur Formation \\
\hline & $-\rightarrow$ & Fawn Limestone & Salkhan Limestone \\
\hline & छี & Olive Shale & Koldaha Shale \\
\hline & ¿ & Porcellanite & Deonar Formation \\
\hline & & Kajrahat Limestone & Kajrahat Limestone \\
\hline & & & Arangi Formation \\
\hline & & Basal conglomerate & Deoland Formation \\
\hline
\end{tabular}

\section{General geological setting}

The Vindhayan Supergroup unconformably overlies the slightly metamorphosed Bijawar Group of rocks with an $\mathrm{Rb}-\mathrm{Sr}$ age of $\sim 2500 \mathrm{Ma}$ (Crawford and Compston 1970). It is constituted of a thick pile of rocks occupying a large area extending from Sasaram (Bihar) in the east to Chittorgarh (Rajasthan) in the west and Dholpur (Rajasthan) in the north to Hoshangabad (Madhya Pradesh) in southwest comprising sandstones, shales and limestones (figure 1). In general, the Vindhyan 
Supergroup is considered to be unmetamorphosed, tectonically less disturbed in most of the areas and one of the best-preserved Proterozoic sedimentary sequences in India. The entire thickness of the Vindhyan Supergroup is divided into four equal groups namely Semri, Kaimur, Rewa and Bhander in ascending order. The Semri Group is best exposed in Son valley area Sonbhadhra District, Uttar Pradesh, where it is divided into different formations (Auden 1933). The eastern most fringe of Vindhyan basin is exposed in the Rohtas District of Bihar. In this locality, only the Semri and Kaimur Groups of rocks are developed. Geology of the eastern part of the basin and general lithostratigraphic succession of the Vindhyan Supergroup in the central part of the basin is given in table 1. The lithostratigraphy of the area has been studied in detail (Sarkar 1981; Sharma 1993; Das Gupta 1997). Here, the estimated thickness of the different formations is $935 \mathrm{~m}$ (Prakash and Kumar 1980).

Salkhan Limestone, overlying the Olive Shales (earlier reported as Nauhatta Limestone Formation by Venkatachala et al 1990) is well-developed, thickly bedded and fawn coloured. It is extremely fine grained, dolomitic and cherty at places, in nature. The gradational to sharp contact have been observed at Jaradag and Nauhatta. The chert bands present in the dolostone stands out on weathering. The chert is typically black to dark greenish black, and its nature gradually changes from the massive, bedded, stromatolitic to again bedded chert in a lithological column.

\section{Age}

The Vindhyan Supergroup unconformably overlies the Bijawar Group of Rocks which are slightly metamorphosed with an $\mathrm{Rb}-\mathrm{Sr}$ age of $\sim 2500 \mathrm{Ma}$ (Crawford and Compston 1970). The age of the new assemblage of microbiota reported from the Salkhan Limestone is poorly constrained in the locality. The only radiometric data available for the Bijaigarh Shale in the study area are based on the $\mathrm{U} / \mathrm{Pb}$ isotope studies of the galena collected at the contact of Bijaigarh Shale and Amjhore Sandstone of Kaimur Group. The lead isotope ratio suggests an age of $725 \mathrm{Ma}$, probably indicating the age of galena mineralisation, which is distinctly syngentic (Balasubramanayan and Chandy 1976).

Recently Rasmussen et al (2002) have provided a robust data set for the Semri Group by using SHRIMP U-Pb Zircon geochronology dating the silicified tuffs. Their studies have shown that the sediments were deposited between $1628 \pm 8 \mathrm{Ma}$ and $1599 \pm 8 \mathrm{Ma}$. Ray et al (2002) dated the rhyolitic volcanic horizons from the
Deonar Formation between the Kajrahat and Rohtas Formation that yield U-Pb zircon ages of $1631 \pm 5 \mathrm{Ma}$ and $1631 \pm 1 \mathrm{Ma}$. Sarangi et al (2004) reported a $\mathrm{Pb}-\mathrm{Pb}$ isochron age of $1599 \pm 48 \mathrm{Ma}$ for the Grypania bearing Rohtas Formation of Vindhyan Supergroup, central India. These results suggest that the Kajrahat Limestone is of the latest Palaeoproterozoic age and the Rohtas Formation is of Mesoproterozoic age. The fossil-yielding horizon of Salkhan Limestone occurring in between is therefore early Mesoproterozoic.

Thus, the comparison and correlation of central Indian Vindhyan sediments indicate that the age of Semri Group of sediments exposed on the eastern-most fringe of the Vindhyan basin range in age from > 1600-1000 Ma. The fossiliferous strata Salkhan Limestone - is considered older than $1400 \mathrm{Ma}$ and about $1600 \mathrm{Ma}$ old.

\section{Previous studies}

The first record of the microfossils from the blackbedded chert of the Salkhan Limestone exposed in the Salkhan area of Uttar Pradesh was reported by Kumar (1978), which was later described in detail by McMenamin et al (1983). In this report ten species belonging to nine genera were reported. In a subsequent publication Kumar and Srivastava (1995) reported a new assemblage of microfossils from Salkhan Limestone exposed in Newari area (Newari is $30 \mathrm{~km}$ west of Salkhan) also in Uttar Pradesh. This report included 28 species belonging to 18 genera representing both coccoid and filamentous forms. The Salkhan Limestone facies extends further east and is well exposed on the easternmost fringe of the Vindhyan basin. The black-bedded chert and other varieties of chert have yielded the well-preserved microbial assemblages that are described and compared in the present paper.

\section{Fossiliferous chert}

Chert is a natural archive of well-preserved microorganisms the world over (Knoll 1985). It provides an insight into the early life and evolutionary trends subsequently opted by these organisms (Knoll and Sergeev 1995; Knoll 1996). The process of preservation is still to be completely understood, yet the cherts where these microfossils are well preserved are most sought after lithology to find an insight into the Precambrian biosphere (Leo and Barghoorn 1976; Maliva et al 1989). Salkhan Limestone exposed in Rohtas District of Bihar shows three main forms of chert, i.e., bedded chert, stromatolitic chert and cherty stromatolites in the field, and all of them proved to be fossiliferous. 

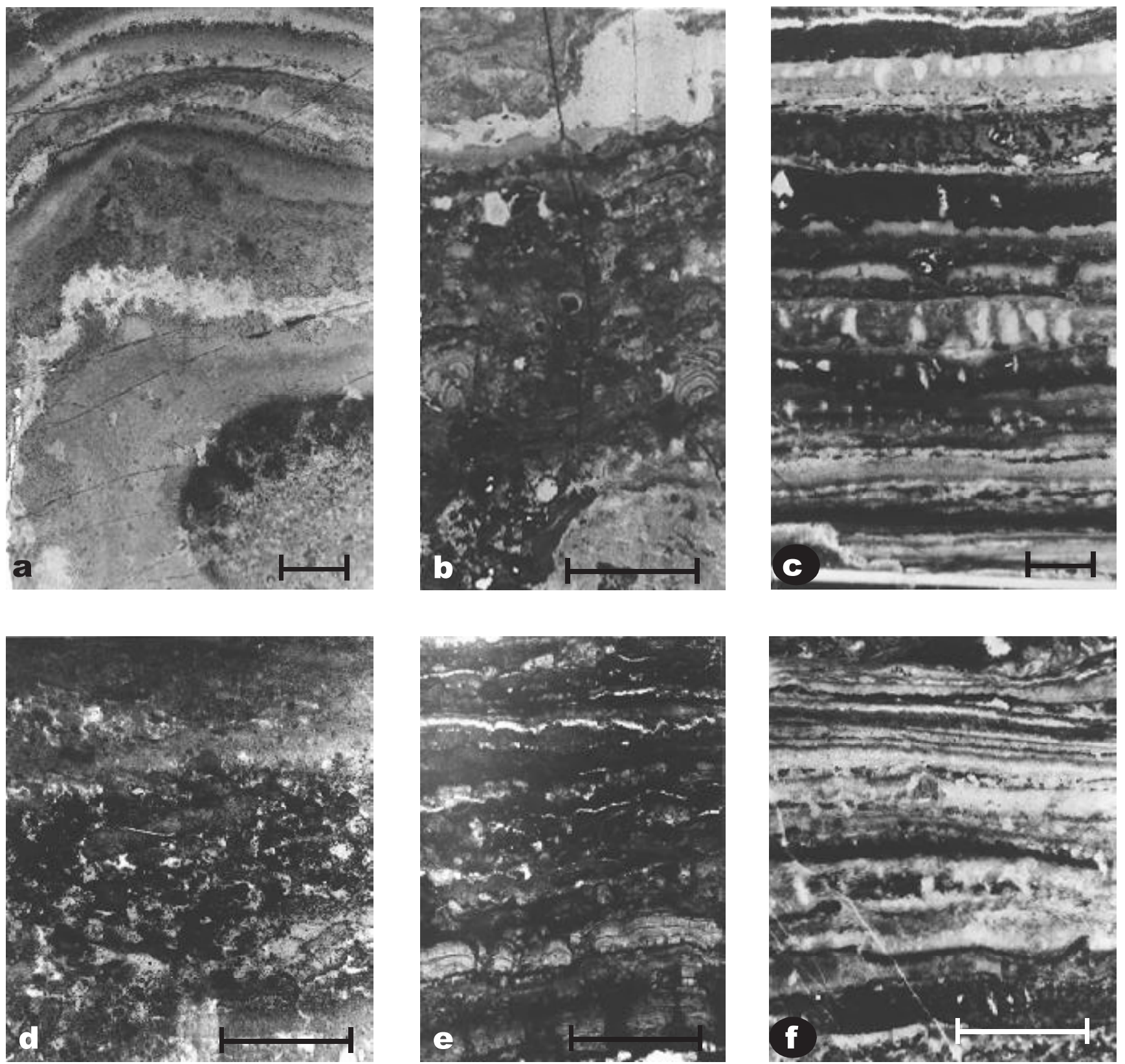

Figure 3. Different types of cherts from the Salkhan Limestone. Note the variations as observed in thin sections. Slide number, bar scale and nature of light used for exposing the thin sections are given in parenthesis. (a) A transitional portion of the section of bedded to stromatolitic chert (BSIP-10903; bar scale $=2 \mathrm{~mm}$, slide exposed under diffused light). (b) A section of stromatolitic chert showing fine stromatolitic columns (BSIP-10911; bar scale $=2.2$ mm, slide exposed under diffused light). (c) and (f) A section of bedded chert in thin section. Note the presence of alternate dark and light laminae. The dark laminae invariably contain varied microfossils. Vugs replaced by chert are present in the light coloured laminae. (BSIP-10908; bar scale $=2 \mathrm{~mm}$, slide exposed under reflected light); (f) bar scale $=1.2 \mathrm{~mm}$. (d) A section of bedded chert in thin section showing ripped up clasts (BSIP-10905; bar scale $=2.2 \mathrm{~mm}$, slide exposed under diffused light). (e) A section of bedded chert in thin section showing tabular nature of stromatolite (BSIP-10906; bar scale $=2.2 \mathrm{~mm}$, slide exposed under diffused light).

\subsection{Bedded chert}

(Figures 3a, 3c-d, 3f; 4a-f, 4i, 4j)

\section{1a Description}

The bedded fossiliferous chert is dense, black, waxy lustrous on freshly broken conchoidal faces. It lies below the stromatolites in the area of study. In the thin section, the chalcedonic grains form an interlocking mosaic pattern and vary from less than $1 \mu \mathrm{m}$ to more than $100 \mu \mathrm{m}$ in diameter with almost amorphous nature tending to be localized in the more fossiliferous areas of the matrix. Quartz grains sometime more than $150 \mu \mathrm{m}$ in 


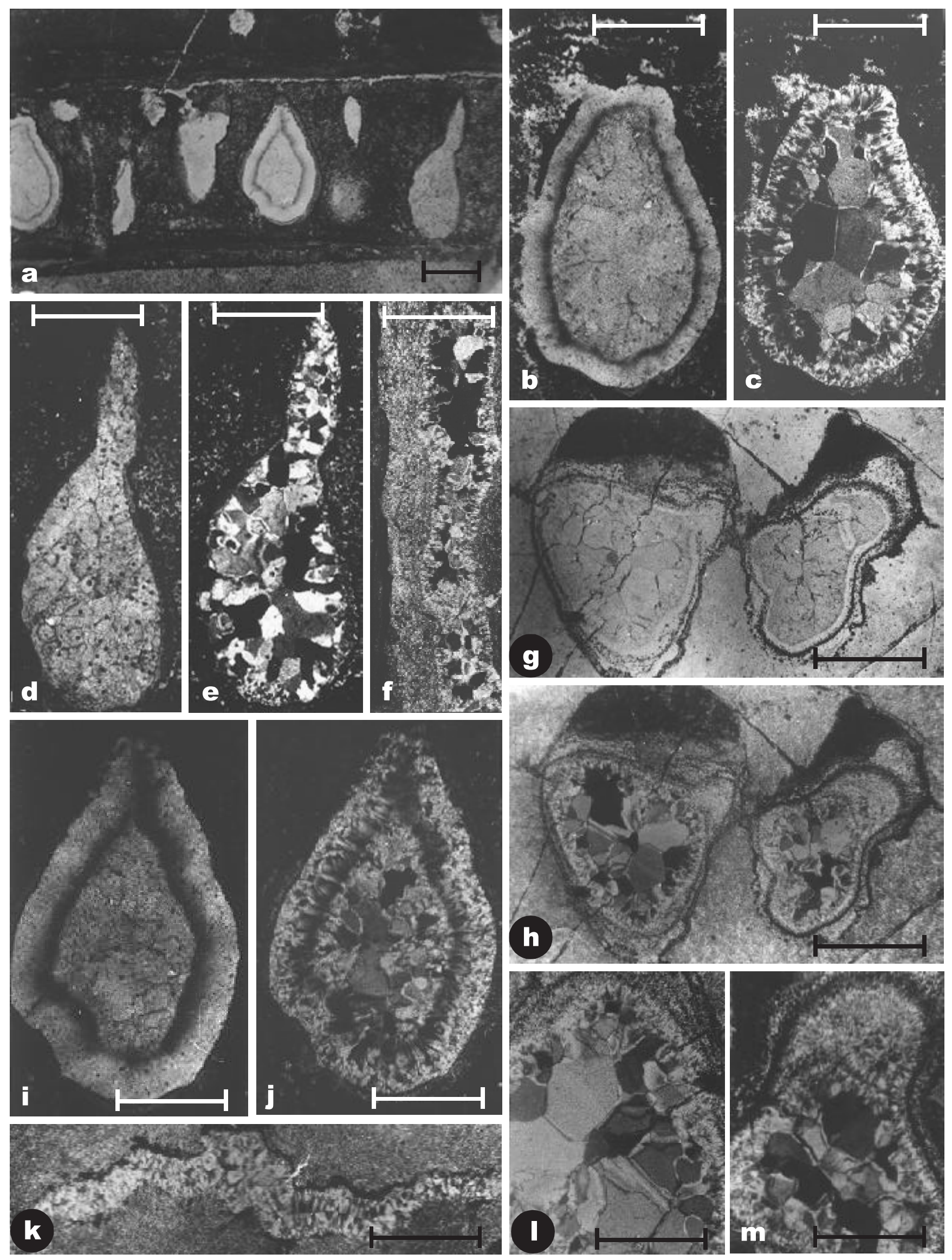


diameter are locally present. Varied well-preserved, randomly distributed sphaeroidal and filamentous microfossils are preserved in a matrix of primary chalcedonic chert with kerogen (microfossils are separately described under systematics section). Multilamellated sheaths, various unnamed forms and sheaths are also recorded. None of these members have any tendency to form organic laminae, or specific preferences for association among the members of assemblage.

\section{$5.1 \mathrm{~b}$ Interpretation}

The presence of micro-organisms in irregular kerogenic brown patches indicate that these microfossils had no role in the formation of overlying stromatolite. The general distribution of microorganisms within the chert matrix and dominance of cyanobacterial elements, strongly suggests that these organisms were present in nearby localities and got entrapped in the zone of silica precipitation. The presence of spherulitic chalcedony (figure 4f) at certain places in the thin section suggests minor alternation in the chert. Except zebraic chalcedony, other elements of replacing chert as suggested by Milliken (1979) are absent in this unit. Therefore it cannot be conclusively considered as a criterion for the replacement nature of the entire chert.

\subsection{Stromatolitic chert}

(Figures 3e; 4g, 4h, 4k, 4l, 4m)

\section{2a Description}

The other form of the chert in Salkhan Limestone is associated with the stromatolites in the locality. Generally, either it is underlying or overlying the stromatolites. Except alternation of dark and light bands of chert no typical stromatolites have been observed in the hand specimens. The dark and light band varies in thickness from few millimeters to centimeter. In thin sections, however, these bands show a variety of stromatolite fabric and texture with varied shapes of precipitates (see Sharma and Sergeev 2004 for precipitate patterns). At few places broken tufted mats, oncoid and oncoidal kerogen and ripped up clasts are also noticed. Sometimes microspar and silica vein impregnations are also noticed in the chert. Fossils are invariably present in dark bands. The white bands show chalcedonic grains of interlocking mosaic patterns from less than $1 \mu \mathrm{m}$ to more than $100 \mu \mathrm{m}$ in diameter. The voids present in light bands are generally constituted of megaquartz, flamboyant quartz, spherulitic chalcedony and zebraic chalcedony and those present in the tufted broken mats are filled with microcrystalline silica. Voids assume a variety of shapes from tear, ovoidal, rounded, polygonal to irregular and devoid of any microbial remains.

\section{$5.2 \mathrm{~b}$ Interpretation}

It is likely that the thin veneer of cyanobacterial blooms or mats present in the open sea got deposited over the regular mats of stromatolitic chert as broken tufted mats, or assumed shapes of oncoid and oncoidal kerogen. The organic matter and kerogen present in the chert impart the black colour to the dark bands of the chert. Like the bedded chert all the elements of evaporite replacing chert have not been recorded in each void. There is a possiblity of chert being primary in nature.

\subsection{Cherty stromatolites}

(Figures 4l, 4m)

\section{3a Description}

Different stromatolitic forms are noticed in the field and their study shows that they are invariably constituted of cherts rather than carbonates (for details of stromatolites see Sharma 1996). In cherty stromatolites, ghosts of carbonate are noted at several places. Proper orientation of lamination could not be noticed in thin sections. Clasts of

\section{Figure 4 caption}

$\overleftarrow{\text { Figure 4. Replacement features of vugs and voids as observed in thin section of bedded and stromatolitic cherts. (a) Note }}$ various shapes of vugs and voids observed in dark lamina of bedded chert (BSIP-10910; bar scale = $1.2 \mathrm{~mm}$, slide exposed under diffused light). (b) and (c) Void observed in bedded chert, (b) in plane polarized light and the same void under cross polarized light (BSIP-10910; bar scale $=1.5 \mathrm{~mm})$. (d) and (e) Elongated upside down voids in bedded chert, (d) under polarized light and the same void under cross polarized light (BSIP-10910; bar scale $=1.5 \mathrm{~mm}$ ). (f) Fine bedded chert showing selective growth of spherulitic chalcedony under cross polarized light (BSIP-13138; bar scale = $1.5 \mathrm{~mm})$. $(\mathrm{g})$ and $(\mathrm{h})$ Void observed in stromatolitic chert in light coloured laminae, (g) under plane polarized light and (h) same void under cross polarized light (BSIP-13145; bar scale $=1.25 \mathrm{~mm}$ ). (i) and $(\mathrm{j})$ Tear shaped upside down void in bedded chert with very thin rim of spherulitic quartzite and mega quartz, (i) under plane polarized light, (j) same void under cross polarized light $($ BSIP-10910; bar scale $=1.5 \mathrm{~mm})$. $(\mathrm{k})$ Note the spherulitic chalcedony in stromatolitic chert (BSIP-13145; bar scale $=1.10 \mathrm{~mm})$. (l) and $(\mathrm{m})$ Enlargements of voids in lighter laminae of cherty stromatolites. Note that voids are constituted of spherulitic chalcedony, megaquartz and flamboyant quartz, (l) under plane polarized light and (m) under cross polarized light $($ BSIP-13145; bar scale $=1.25 \mathrm{~mm})$. 
kerogen are floating in amorphous silica. Voids are scattered in stromatolites. Void fillings, spherulitic chalcedony, zebraic chalcedony and flamboyant quartz are present in the voids. Microfossils content in these cherts are poor and only some filamentous forms are observed.

\section{3b Interpretation}

Presence of ghosts of carbonate in the chert thin section as well as microtexture and fabric studies indicate that stromatolitic carbonate has been replaced with chert and most of the cherty stromatolites are formed by the replacement of carbonate rocks or sediments. The stromatolitic laminae and kerogen have also contributed towards the black colour stromatolites. The presence of voids in between the stromatolitic laminae and spatial relationships of void and replacement features suggest that prior to lithification of the mats, there was a short phase of desiccation and an evaporite development. Thus it is reasonably clear to conclude that the microbial assemblage of Salkhan Limestone grew in arid, intertidal to supratidal environment where some evaporitic minerals could have formed contemporaneously with the mat formation or very likely soon thereafter.

\section{Palaeoenvironmental interpretation of microfossils}

The microfossils of Salkhan Limestone are three dimensionally preserved in a structurally little altered condition as organic residue within the bedded, stromatolitic as well as chertified stromatolities. The dark brown colour imparted to the chert by the organic residue testifies that the original organic compounds have been a little altered except for the thermal alteration. In different types of cherts, solitary, planktic and randomly occurring microfossils are considered mat dwellers as inferred by the orientation and density of microfossils. Those occurring in groups in organized fashion and benthic in nature are termed as mat builders. Similar association of taxa in a structured pattern of community occurs in Bahamania environment and in the Proterozoic succession of the East Greenland (Green et al 1987).

It is likely that the microbial assemblage of the Salkhan Limestone grew in shallow, relatively saline water. This is suggested by analogy with modern entophysalidacean mats that occur in arid, shallow-water environments often in intertidal to supratidal flats (Logan et al 1974; Horodyski and Von der Haar 1975; Golubic 1973, 1976; Kinsman and Park 1976; Playford and Cockbain 1976; Walter 1976; Horodyski et al 1977; Margulis et al
1980; Sergeev et al 1995, 1997). No relicts of evaporite minerals are so far found in the Salkhan Limestone yet the voids, vugs and replacement sequence of carbonates to chert suggest their formation and successive replacement in some cases. The other parameter is the evidence for the original pigment concentrations in the upper parts of the microbial mats constituted by E. belcherensis. Analogous conditions of colouring in modern Entophysalis is apparently a response to highlight intensity and is characteristic of cyanobacteria that live in areas of high salt content (Fritsch 1945; Drouet 1968; Fogg et al 1973; Walsby 1974).

The noticeable difference in the composition and level of preservation of the biota in different types of cherts suggests that each one of them represents a different zone of carbonate tidal flat of intertidal to supratidal region. Similar assemblages are reported in various Proterozoic basins from different parts of the world (Knoll et al 1989, 1991; Sergeev et al 1997). It is presumed that the biological communities preserved in different cherts may be analogous to those described from several extant environmental niches such as in the Hamelin Pool, Shark Bay (Logan et al 1974), Coastal lagoon, laguan Mormona, Baja California, Mexico (Horodyski et al 1977; Margulis et al 1980; Green et al 1987). The well-preserved mats of Eoentophysalis recorded in the stromatolitic cherts seem to be analogous with the 'pustular mats' built by Entophysalis major in the middle to upper intertidal zones of the Hamelin Pool. The compressed mats of Eoentophysalis in the same chert forming organic laminae may be compared with the 'film mats' (desiccated ecomorphs of pustular mat; see Logan et al 1974, p. 146 for their discussion of film mat) reported from the upper intertidal to supratidal zones of the Hamelin Pool. The microbial assemblage consisting of Tetraphycus and Sphaerophycus resembles the population reported from 'gelatinous mat' in the lower to middle intertidal zones of Hamelin Pool.

Stratiform stromatolites particularly the Stratifera irregularis and Irregularia sp. occurring in Salkhan Limestone appear to have been built by Eoentophysalis belcherensis, a coccoidal, entophysalidacean cyanobacteria which are well preserved and very abundant in the stromatolitic chert. Coccoid unicells of the genus Myxococcoides are common in the assemblage and probably represent fossilized chroococacean cyanobacteria. Different species of Myxococcoides either occur along with the Eoentophysalis mats or are dispersed freely in organic mass/kerogen. This spatial relationship suggests that Myxococcoides were mat dwellers rather than actually having contributed to the building of the organic laminae. The other important constituents of stromatolitic 
chert include Eosynechococcus grandis, E. moorei, Palaeoanacystis vulgaris, some species of Sphaerophycus and Tetraphycus. Of these the species of Eosynechococcus and Palaeoanacystis along with a large amount of mucilaginous sheath suggest their growth in arid and harsh conditions. Their isolated and patchy distribution above the Eoentophysalis mat/layers in darker laminae, sometimes even transgressing into the lighter laminae, suggests that these forms were free floating.

Numerous solitary sporangia like spheroids of Clonophycus elegans, C. ostiolum, Conhemisphaera pendulua occur in the stromatolitic chert. These fossils resemble endosporangia of cyanobacteria or sporangia of the type that contain asexual, non-motile spores. Members of Clonophycus and Conhemisphaera, occur as solitary and in isolation with other cyanobacterial assemblage of the chert in part of dark organic laminae and precipitates. This spatial distribution suggests that these organisms lived unattached to substrate. Number of cells have been recorded in the stromatolitic chert but have not been detected in the bedded chert as well as in the cherty stromatolites. It is likely, therefore, that the restricted occurrences of these forms may be due to the biological relationship among Clonophycus, Conhemisphaera and Eoentophysalis, common in the same locality. These fossils present interesting details of the mode of reproduction through endospores or akinetes, which have rarely been found preserved in fossil record (e.g., Sergeev et al 1995; Kumar and Srivastava 1995; Srivastava 2005). These are identified with the help of extant genera, to which they are remarkably similar.

Conhemisphaera shows formation of 8 endospores in each small spherical cell, which apparently are dispersed by the rupture of cell walls. Some of the specimens have large smooth walled 'Spherical Cells'. They do not show cell division. It is probable that these may represent isolated instances of smooth walled akinetes bereft of vegetative cells. Preservation of a germling of a few cell lengths inside a large spore provides support to the aforesaid interpretation. Probably it is a homocystous anabaenoid alga.

Cellularly preserved, filamentous organisms are rare in this assemblage. Only some mulitlamellated sheaths and unnamed organic forms have been observed. Absence of cellular details in filamentous forms and patchy organic mass dispersed in the chert support the view that these forms may also have washed into the realm of precipitating chert. However, the possibility of preferential preservation of coccoid forms over the filamentous forms cannot be ruled out. Cherty stromatolites show preferential preservation of filamentous forms over coccoid forms in the stromatolitic chert. Microfossils are confined to darker laminae of the stromatolites. Some of them are parallel to the laminae, where as Oscillatoriopsis and Siphonophycus cut across the darker and lighter laminae. Tussocky texture of the stromatolite is probably due to the overgrowth of filamentous forms showing their gliding movement for sunlight. Broken and small-scale texture suggest agitation environment, which prohibited the growth of large size columnar stromatolites leading to the formation of a new type of stromatolite Rohtasia harnaensis (Sharma 1996).

\section{Comparison with other Proterozoic microfossils}

\subsection{Kheinjua Formation microfossils}

The microfossils of the Salkhan Limestone are quite similar to those described by (Kumar 1978; McMenamin et al 1983; Kumar and Srivastava 1995) from Fawn Limestone of Kheinjua Formation ( 1600 Ma) Semri Group, Vindhyan Supergroup, India. Five genera including a minimum of two species are common to both assemblages. In both the deposits Eoentophysalis belcherensis dominates the preserved microbes and appears to have formed stratiform stromatolites in shallow arid environments. E. belcherensis in the two localities has darkly coloured margins and many of the same degradational forms of this and other species occur in each assemblage. Both biotas contain few well preserved filamentous microfossils and it is possible that some of the unicells from Kheinjua Formation assigned to Khienjuasphaera vulgaris, Melasmatosphaera media may be conspecific with the unicells described as Clonophycus, Conhemisphaera from the Salkhan Limestone.

Nevertheless, the Salkhan assemblage includes numerous genera and species that appear to be absent from Kheinjua deposits and Kheinjua microbiota includes distinctive forms such as Gunflintia minuta, Kheinjuasphaera vulgaris, Melasmatosphaera media and Glenobotrydion aenigmatis, besides different species of Myxococcoides, Eosynechococcus, Tetraphycus and Eoentophysalis.

\subsection{Microfossils of the Chitrakut area}

Kumar and Srivastava (1992a) in a preliminary report described the two microfossils from the chert present in the basal most part of the Semri Group. Recently, Anabarasu (2001) recorded acritarch Cymatospheroides kullingii and unnamed form ' $\mathrm{A}$ ' from the non-stromatolitic Glauconitic Limestone Member of Chitrakut Formation. The chert occurs as thin specks and lens. The unnamed filamentous 


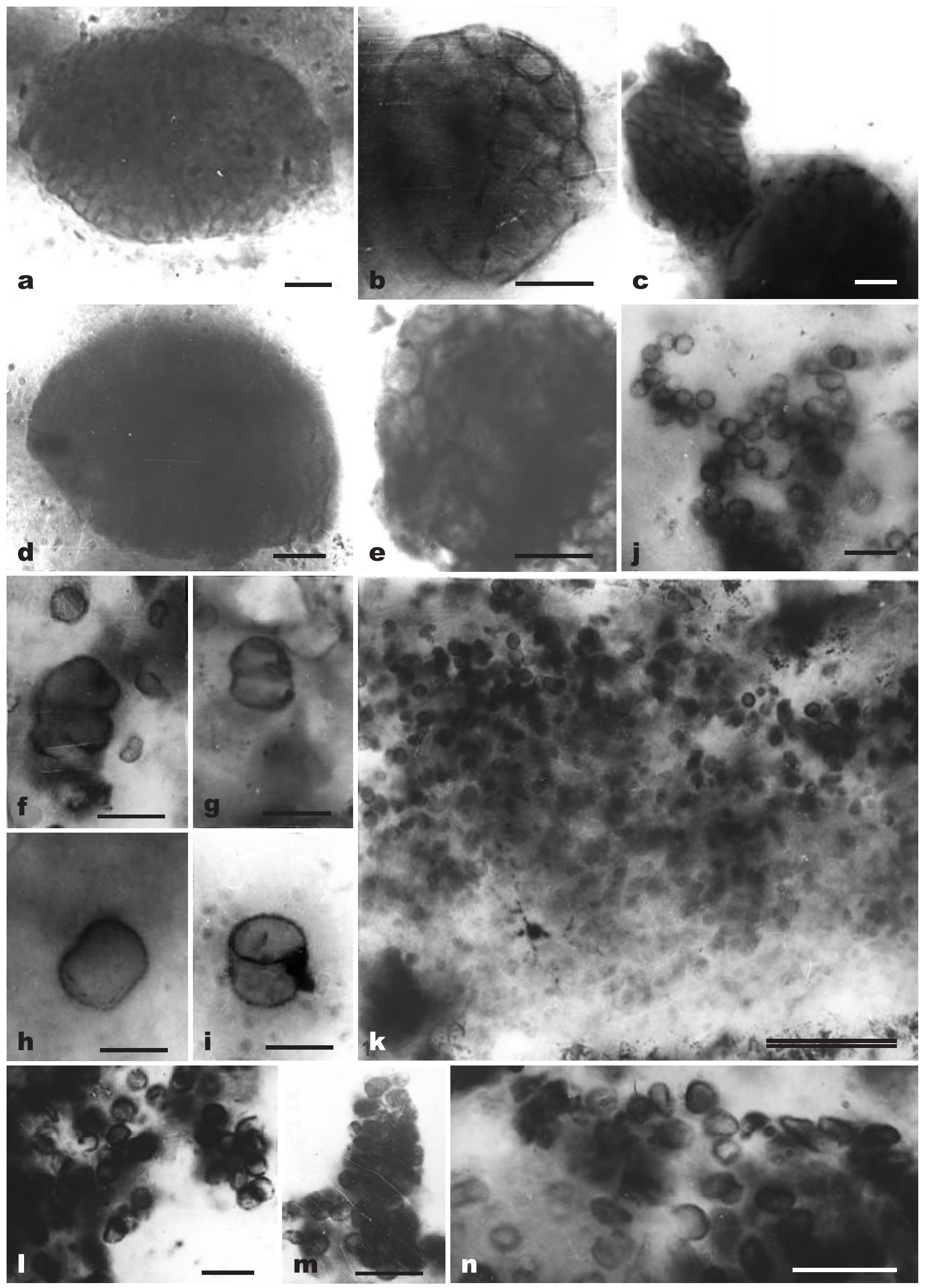


form and an acritarch Trachysphaeridum noticed in Chitrakut chert are absent in the Salkhan assemblage. No conclusive comparison is possible except that microbial assemblage grew at several localities at various stratigraphic levels in Vindhyan Supergroup, and in Semri Group in particular.

\subsection{Comparison with other Mesoproterozoic formations of the world}

The microbiota of the Salkhan Limestone is quite similar to that described from other Mesoproterozoic localities of the world, viz., Balbirini Dolomite, McArthur Group of Australia ( 1500 Ma) by Oehler (1978); the Dismal Lakes Group (1250 Ma) of Arctic Canada by Horodyski and Donaldson (1980); Cliffs Formation and Victor Bay Formation of Uluksan Group ( 1250 Ma), Bylot Supergroup, Canada by Hofmann and Jackson (1991). Eoentophysalis is conspicuously absent in Uluksan Group. The Salkhan Limestone, can therefore be termed 'typical Mesoproterozoic microbiota'.

\section{Significance of the microfossils}

With 27 morphotypes belonging to fourteen genera, twenty-one species and six unnamed forms, the Salkhan microbiota exhibit considerable taxonomic diversity. The biological affinities of many of the taxa remain uncertain, although they can be considered prokaryotic benthic and planktic forms (cyanobacteria) (compare with assemblages described by Hofmann and Schopf 1983, p. 349-359).

The most common mat forming benthic form is Eoentophysalis and to some extent Eosynechococcus a coccoid cyanobacteria and Siphonophycus is the individual filamentous form. The assemblage includes several planktonic forms washed into the stromatolitic environment. The Eoentophysalis dominated assemblage of the Salkhan Limestone provides probably the best biological point of comparison between the modern and ancient environment in totality. Salkhan Limestone is strikingly similar to the modern environment for the consideration of microbial morphologies, taxonomy, morphology of the associated stromatolites and position within the carbonate intertidal zone.

Entophysalid-dominated mat association is a characteristic of a number of Proterozoic Formations, the oldest being the $2000 \mathrm{Ma}$ old cherts of the Kasegalik and McLeary Formations, Belcher Islands Canada (Hofmann 1976) and the youngest being the $570 \mathrm{Ma}$ old Yudoma Suit, Eastern Siberia (Lo 1980). The other younger and older Eoentophysalis dominated assemblages have been reported from 1500 Ma Amelia Dolomite, Australia (Muir 1976), the slightly younger Balbirini Dolomite, also of Australia (Oehler 1978), 1400-1500 Ma old Gaoyuzhuang Formation, China (Zhang 1981), the $1200 \mathrm{Ma}$ old Dismal Lakes Group, Canada (Horodyski and Donaldson 1980) and the 750-790 Ma old Bitter Springs Formation, Australia (Knoll and Golubic 1979), 1500 Ma old Debengda Formation, Siberia (Sergeev et al 1994), 1500-1250 Ma old Billyakh Group (Sergeev et al 1995). Depositional environment and ecological parameters seem to be similar in all the instances testifying the persistence of a unique community type in a single environment throughout some 2000 Ma of the earth history fighting and winning for its existence. Most of the taxa of the Salkhan Limestone assemblage are long ranging prokaryotes, the overall character of the assemblage is characteristically Mesoproterozoic with its major features comparable to the coeval floras of Australia, Canada, China and Russia.

The biostratigraphic significance of Salkhan microbiota is very limited. Most of the taxa including the rarely occurring nonseptate filaments and small coccoids are long ranging in age. They are abundant in the Proterozoic and even continue into the Phanerozoic. However, the Salkhan assemblage contains taxa such as Clonophycus which is characteristic of the Mesoproterozoic microbiotas such as 1500 Ma old Balbirini Dolomite (Oehler 1978). The other forms show a long range extending into the Neoproterozoic. In comparison with known palaeobiological records, silicified biota of Salkhan assemblage can be dated $\sim 1600 \mathrm{Ma}$, consistent with the age for the Semri Group based on radiometric and stromatolite biostratigraphic data.

\section{Figure 5 caption}

$\overleftarrow{\text { Figure 5. Microbial assemblage recorded from Salkhan Limestone of the Semri Group. In this and all following figures, }}$ slide catalogue number for the Birbal Sahni Institute of Palaeobotany Museum (BSIP) and co-ordinates for each fossil or population illustrated are given in brackets. $\mathrm{X}$ and $\mathrm{Y}$ slide co-ordinates given are for Leitz Diaplan Microscope. (a-e) Coniunctiophycus majorinum Knoll et al (a) (BSIP-10907; 40.3/100.0), (b) (BSIP-10907; 40.3/103.5), (c) (BSIP-10907; 40.2/100.0), (d) (BSIP-10907; 40.0/101.8), (e) (BSIP-10906; 33.4/98.3). (f-i) Diplococcus sp. (f) (BSIP-10905; 38.5/108.3), (g) (BSIP-10906; 36.5/108.6), (h) (BSIP-13145; 37.0/97.0), (i) (BSIP-10907; 34.4/105.1). (j, k, m, n)-Sphaerophycus medium Horodyski and Donaldson, (j) (BSIP-10905; 29.0/105.4), (k) (BSIP-13140; 39.3/102.1), (m) (BSIP-13142; 26.4/96.9), (n) (BSIP-10906; 34.6/99.3). (l) Sphaerophycus parvum Schopf (BSIP-13142; 49.0/107.4). Single scale bars $=10 \mu \mathrm{m}$; double bars $=50 \mu \mathrm{m}$. 
The Salkhan microfossils add significant data on the habit of cyanobacteria during Precambrian Eon. The colonial habit of cyanobacteria as represented by five genera of colonial coccoid microfossils in the Salkhan assemblage is a testimony of regular colonial morphologies and polarity of organisation as exhibited by Eoentophysalis, Myxococcoides, Eosynechococcus and Palaeoanacystis.

The occurrence of Clonophycus and Archaeoellipsoides in the Salkhan assemblage representing algal sporangia/akinete suggests that the sexual mode of reproduction through endospores/akinetes/sporangia may have developed by the close of Mesoproterozoic at least $1200 \mathrm{Ma}$ ago. The Eoentophysalis, which is an endopsore forming cyanobacteria, is wide spread in the Salkhan assemblage. The occurrences of this cyanobacteria from $2000 \mathrm{Ma}$ to $700 \mathrm{Ma}$ old sediments from Belcher Island Formation to Narssarssuk Formation provides circumstantial evidences for the earlier development of the process of endospore formation. The other apparent examples of Precambrian sporangia or sexual mode of reproduction include $700 \mathrm{Ma}$ old endosporangia of Sphaerocongregus variabilis Moorman (Moorman 1974; Cloud et al 1975) and the type species of Clonophycus (Oehler 1977) from the H.Y.C. microbiota the $C$. elegans and other species of the same genera C. ostiolum, C. refreingens, C. vulgaris and Clonophycus sp. from Balbirini Dolomite (Oehler 1978). Recently well-preserved akinetes of heterocystous cyanobacteria have been recorded from several Mesoproterozoic localities (Golubic et al 1995; Sergeev et al 1995; Knoll and Sergeev 1995; Srivastava 2005).

\section{Samples, method and repository}

The material for the present investigation was collected during 1988 and 1990 field visits. Outcrop samples of black-bedded chert, stromatolitic chert and cherty stromatolites were collected from the Nauhatta, Harna and Sihaldeh localities. Cutting samples from dug wells of stromatolitic chert were collected from Harna locality. All the localities are in the Rohtas district of Bihar in India. The microbiota of the Salkhan Limestone are studied in petrographic thin sections by optical microscopy using transmitted light. The mineralogy of the samples was studied in petrographic thin sections by optical microscopy using transmitted and polarised light. The sizes of microfossils were measured in thin sections using an eyepiece micrometer. All the relevant slides are housed in the repository of Birbal Sahni Institute of Palaeobotany Museum bearing slide nos. BSIP-10903, 10905, 10906, 10907, 10908, 10910, 10911, and 13138-13145.

\section{Systematic palaeontology}

On the basis of comparable size, morphology and colony shape, it has been attempted to place microfossils in the extant groups of cyanobacteria. There is no agreement to adopt a single classification scheme for taxonomic dealing of organic-walled microfossils and a general consensus agreement is still to be developed. Presently most of the existing systems of extant cyanobacteria classification consider the following features: nature of any sheath or gelatinous matrix surrounding the cells; presence of specialised cells such as akinetes, heterocysts, and the trichomes of filamentous species; size and characteristics of vegetative cells; presence of pseudovacuoles; presence and types of branching of filamentous species and ultimately the ecological role. Some of these features are taken into account while dealing with the systematics of fossils cyanobacteria of the Salkhan assemblage of Rohtas District, Bihar. The role of preservation and its effect on changes in morphology cannot be negated and is taken into account while describing the chroococcacean members. The fossils described here can be divided into two broad categories: filamentous forms and coccoidal forms.

Kingdom: Eubacteria, Woese and Fox 1977

Phylum: Cyanobacteria, Stainer et al 1978

Class: Coccogoneae, Thuret 1875

Order: Chroococales, Wettstein 1924, emend. Rippka et al 1979

Family: Chroococcaceae, Nägeli 1849

Genus: Coniunctiophycus, Zhang 1981

Type species: Coniunctiophycus gaoyuzhuangense Zhang 1981

Stratum typicum: Gaoyuzhuang Formation, China.

Coniunctiophycus majorinum Knoll et al 1991 (Figures 5a-5e)

Coniunctiophycus majorinum Knoll et al 1991, p. 554, 557, figures 16.1-16.4.

Description: Sphaeroidal to elongated organic walled cells, occasionally polygonal, walls thin, finely granular, arranged in packets of 50-100 cells, 20-100 $\mu \mathrm{m}$ long and $30-50 \mu \mathrm{m}$ wide. Unit cells of pluricellular colonies range in size $2-5 \mu \mathrm{m}(2.4 \mu \mathrm{m}$, wall $0.5 \mu \mathrm{m}, 100$ cells measured), no external mucilage is apparent. Generally clumped in more or less globular colonies composed of more than 400 cells. Larger packets of cells form distinct lobes, generally accentuated due to post preservation changes. Colonies elongated parallel to bedding. No differentiation of cells within colonies. Surface texture psilate. Cells not individually covered but colonies are encompassed by organic mucilaginous sheath. Cells randomly and compactly arranged 
in the colonies. Reproduction by fission in three mutually perpendicular planes. Compactness of the colonies is probably due to daughter cells remaining aggregated. New colonies are probably formed by the fragmentation of the pre-existing colonies.

Discussion: Coniunctiophycus majorinum colonies occur in stromatolitic cherts. Their colonial habit compares closely with certain pleurocapsalean cyanobacteria like Myxosarcina and Chroococcidiopsis (Waterbury and Stainer 1978). But other cyanobacteria (e.g., Entophysalis sp.) and other Eubacteria and certain protists (like Chlorosarcina) may assume such shape. Zhang (1981) described the genus Coniunctiophycus as complex aggregated colonies of a number of spheroidal cells. He compared this habit to the living planktonic chroococcoid cyanobacteria Microcystis, Coelosphaeridium and Aphanotheca. The Salkhan assemblage of Coniunctiophycus conforms in all salient features to Zhang's (1981) generic diagnosis. In specific diagnosis it is also closely comparable to Draken population of C. majorinum (Knoll et al 1991). Zhang (1981) assigned the Coniunctiophycus gaoyuzhuangense to the family Chroococcaceae, close similarity of the present specimens with Coniunctiophycus and in absence of any reproductive body no firm systematic assignment is possible. Although Knoll et al (1991) placed Coniunctiophycus under incertae sedis but considering Zhang's (1981) proposition it has been grouped in Chroococcaceae.

Distribution: Mesoproterozoic: the Gaoyuzhuang Formation, China; the Kotuikan and Yusmastakh Formations, Anabar Uplift, northern Siberia; the Salkhan Limestone, Semri Group, Vindhyan Supergroup.

Material: More than a dozen colonies from Salkhan Limestone.

\section{Genus: Diplococcus sp.}

Type Species: Diplococcus sp.

Stratum typicum: Salkhan Limestone.

\section{Diplococcus sp.}

(Figures 5f-5i)

Diplococcus shaped Microstructures Lo 1980, p. 160, Pl. IV, figures 12-15.

Description: Spherical to hemispherical cells, solitary or in pairs, occasionally forming planar colonies. Surface of cells smooth to thickly granular, cell range in size from $2-5 \mu \mathrm{m}$ (average $2.8 \mu \mathrm{m}$, 125 cell measured). Paired cells are $3-5 \mu \mathrm{m}$ long (average $4.0 \mu \mathrm{m}, 10$ specimens measured).

Discussion: These forms are common in bedded and stromatolitic chert assemblage and are distributed in the chert along the bedding plane. Diplococcus is similar to several living Chroococalean members and resemble dividing Chroococcaceae cells representing binary fission. Some of the cells, which are larger in size noted in the assemblage of bedded chert, do not commonly have dividing line across the cell, yet all other characters like mode of occurrence, surface structure, etc. are similar. Hence they have been categorized under Diplococcus like cells. Similar cell like units have been reported from Bitter Springs assemblage as Sphaerophycus Schopf (1968), in Belcher Island assemblage as Eoentophysalis Hofmann (1976) but they differ only in size parameter.

Distribution: Palaeoproterozoic: Belcher Islands, Canada; Mesoproterozoic: Salkhan Limestone of Semri Group, India; Neoproterozoic: Yodoma Suite, Siberia; Bitter Springs, Australia.

Material: More than hundred specimens noticed.

Genus: Eosynechococcus Hofmann 1976 emend. Golovenok and Belova 1984

Type species: Eosynechococcus grandis Hofmann 1976 emend. Golovenok and Belova 1984

Stratum typicum: McLeary Formation, Canada. Eosynechococcus grandis Hofmann 1976

(Figures 7e-7g, 7l)

Eosynechococcus grandis Hofmann 1976, p. 1058, Pl. 2, figures 11-14. emend.; Golovenok and Belova 1984 , p. 28 (p. 24 english version), Pl. 2, figure 1; Hofmann and Jackson 1991, p. 372, figures 7.18, 7.19, 9 (partim).

Description: Cells long, ellipsoidal, rod shaped to barrel shaped, sometimes rounded. Envelope not distinct. Cells solitary, due to clumping some of the cells are adpressed and aggregated in irregular clumps, slightly constricted. Division by transverse fission. No dark inclusions found. $10-18 \mu \mathrm{m}$ long and $5-7.0 \mu \mathrm{m}$ across, averaging $14.5 \times 6.0 \mu \mathrm{m}(10$ specimens measured).

Discussion: Salkhan population of Eosynechococcus grandis confirms in all salient features to the specimens described by Hofmann (1976) emended by Golovenok and Belova (1984). They have considered these forms as akinetes. It has been noticed in the stromatolitic chert of the Salkhan Limestone occurring above the dark laminae of the stromatolites.

Distribution: Palaeoproterozoic: the McLeary Formation, Belcher Supergroup, Canada; Mesoproterozoic: the Uluksan Group, Bylot Supergroup, Canada; the Salkhan Limestone, Semri Group, Vindhyan Supergroup.

Material: Several specimens in Salkhan Limestone.

Type species: Eosynechococcus moorei Hofmann 1976

Stratum typicum: Kasegalik Formation, Belcher Supergroup, Canada.

Eosynechococcus moorei Hofmann 1976

(Figures 7h-7k) 
Mukund Sharma

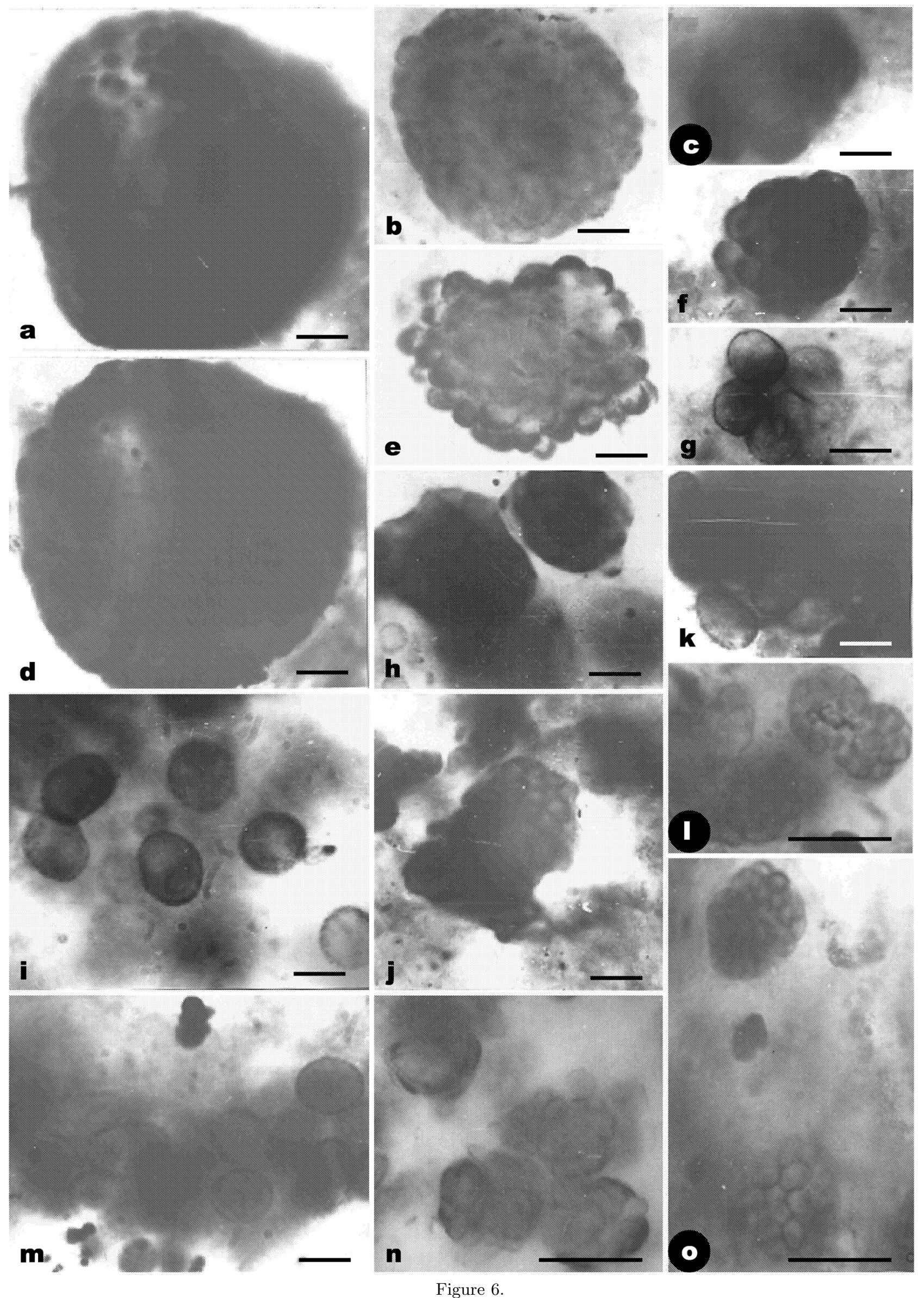


Category 1 microfossils Hofmann 1974, p. 88, figures 1b, c; Category 2 microfossils Hofmann 1974 (partim), p. 88, figure 1g.

Eosynechococcus moorei Hofmann 1976, p. 1057, 1058, Pl. 2, figures 1-7, 8?; Knoll et al 1991, p. 557, figure 17.16-17.22.

Description: Cells oblong, ellipsoidal to long rod shaped, sometimes curved to slightly constricted on one side. No covering envelope observed. Occurring solitary and loosely or closely aggregated forming irregular clumps or bowl shaped. Constriction probably representing transverse cell division can be seen. Centrally or eccentrically positioned, no dark object noticed. Dimension of cells $3-8 \mu \mathrm{m}$ long and $2-3 \mu \mathrm{m}$ across (average $5 \times 2.3 \mu \mathrm{m} ; 50$ cells measured).

Discussion: Population of Eosynechococcus moorei in the Salkhan assemblage have been found in stromatolitic chert. It loosely occurs over the dark laminae, probably they may not have any role in the formation of stromatolitic laminae. Salkhan population of Eosynechococcus confirm in all salient features with the diagnosis provided by Hofmann (1976). But contrary to the Salkhan population, specimens described from Kasegalik Formation have occasional occurrence of dark inclusion and are slightly larger in size. Knoll et al (1991) argued that these could be remains of chroococcalean cyanobacteria, but all could alternatively be the remains of physiologically dissimilar eubacteria and treated them as incertae sedis.

Distribution: Palaeoproterozoic: the Kasegalik Formation, Belcher Supergroup, Canada; Mesoproterozoic: the Salkhan Limestone, Semri Group, Vindhyan Supergroup; Neoproterozoic: the Draken Conglomerate Formation, Spitsbergen.

Material: A few dozens of specimens in the Salkhan Limestone.

\section{Genus: Myxococcoides Schopf 1968}

Type species: Myxococcoides minor Schopf 1968 Stratum typicum: Bitter Springs Formation, Australia.

Myxococcoides minor Schopf 1968

(Figures 6g, 6i, 6k, 6m; 7m)

Myxococcoides minor Schopf 1968, p. 676, Pl. 81, figure 1, Pl. 83, figure 10, table 4; Hofmann 1976, p. 1061, Pl. 7, figures 4-8; Knoll 1982b, p. 784-785, Pl. 8, figures 3, 4; McMenamin et al 1983, p. 258, figure 5B, C; Zhang and Gu 1986, p. 326 (p. 18 english version), Pl. II-2, 5; Hofmann and Jackson 1991 , p. 374, figures 8.1-8.5, 11; Kumar and Srivastava 1992c, p. 300, figure 8A, Text figures 4, 5, 11.

Description: Cells commonly sub-spherical to ellipsoidal somewhat flattened by compression against the adjacent cells. Clubbed into globular colonies. Surface structure smooth to finely granular. Cell dimension $6 \mu \mathrm{m}-13 \mu \mathrm{m}$ (averaging $10.5 \mu \mathrm{m} ; 50$ cells measured). Cells are enveloped in a granular to non-lamellated organic matrix; number of cells per colony varies from 40-60. Cells randomly oriented in the colony. Occasionally distorted due to mutual compression.

Discussion: Cells of this species are common in the stromatolitic cherts. The form Myxococcoides minor Schopf is morphologically similar to the ones described by Schopf (1968) except for the smaller size of Salkhan population. It is also comparable to M. minor described by McMenamin et al (1983). Specimens of Myxococcoides ovata have been noted in the bedded chert. In general morphology these specimens resemble the Myxococcoides ovata Knoll recorded from Akademikerbreen Group, Svalbard. Distribution: Mesoproterozoic: the Uluksan Group, Bylot Supergroup, Canada; the Kheinjua Formation, Semri Group, Vindhyan Supergroup, India; Neoproterozoic: the Bitter Springs Formation, Australia.

Material: A few dozen specimens are recorded in Salkhan Limestone.

Genus: Palaeoanacystis Schopf 1968

Type species: Palaeoanacystis vulgaris Schopf 1968

Stratum typicum: Bitter Springs Formation, Australia.

Palaeoanacystis vulgaris Schopf 1968

(Figures 6a-6e)

Palaeoanacystis vulgaris Schopf 1968, p. 672-675, Pl. 82, figures 5-7, table 4; Hofmann 1976, p. 1061, pl. 5 , figures $1-2$.

Description: Cells sphaeroidal to ellipsoidal, seldom angular due to mutual compression, aggregated in more or less sphaeroidal colonies, rarely solitary, clumped into mass of more than 300-400 cells. Cells diameter varies between 2 and $5 \mu \mathrm{m}$, with an average diameter of $4.0 \mu \mathrm{m}$, cell walls

\section{Figure 6 caption}

$\overleftarrow{\text { Figure 6. Microbial assemblage recorded from Salkhan Limestone of the Semri Group. (a-e) Palaeoanacystis vulgaris Schopf, }}$ (a) (BSIP-10906; 34.0/99.7), (b) (BSIP-10907; 40.3/100.0), (c) (BSIP-10906; 31.2/96.4), (d) (BSIP-10906; 34.0/99.7), (e) (BSIP-10907; 40.2/100.0). (f, h, j, l, n, o) Palaeoanacystis minor sp. nov. (f) (BSIP-10906; 27.0/97.6), (h) (BSIP-13142; 48.9/106.3), (j) (BSIP-13142; 37.6/92.5), (l) (BSIP-13141; 43.0/104.6), (n) (BSIP-13141; 33.4/97.1), (o) (BSIP-13141; 43.1/103.6). (g, i, k, m) Myxococcoides minor Schopf, (g) (BSIP-13142; 42.4/96.5), (i) (BSIP-10906; 38.8/103.2), (k) (BSIP$13142 ; 42.4 / 96.5)$, (m) (BSIP-13139; 33.1/95.6). Single scale bars $=10 \mu \mathrm{m}$. 

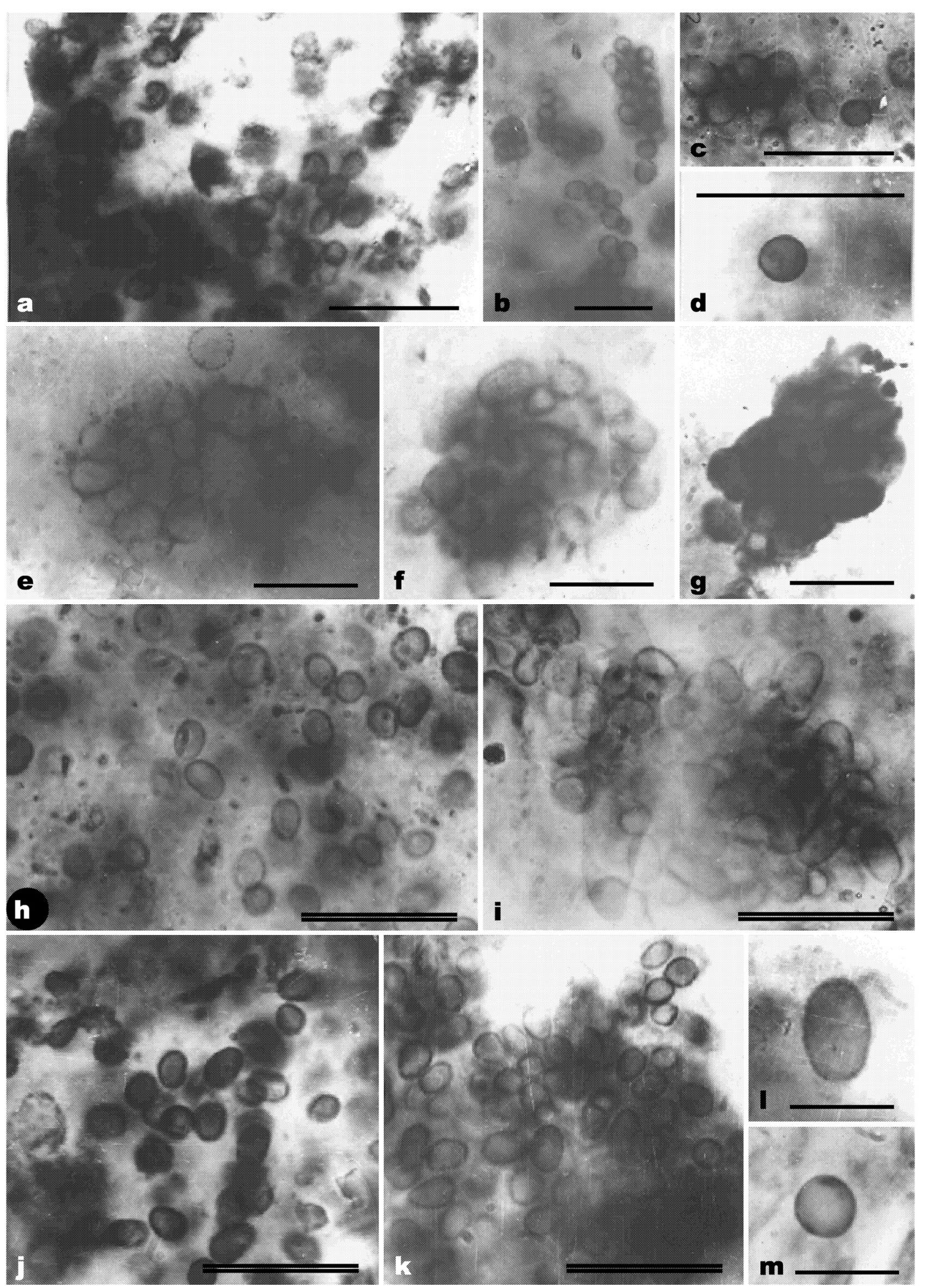

Figure 7. 
robust and psilate, $1 \mu \mathrm{m}$ thick. Individual cells are not surrounded by sheath. Reproduction by fission. It is observed that daughter cells remain aggregated, new colonies are formed by the fragmentation of the daughter colonies.

Discussion: Salkhan population of Palaeoanacystis vulgaris has been noted in stromatolitic chert of Salkhan Limestone. It confirms in all the diagnostic characters of Schopf's (1968) specimen. P. vulgaris is one of the more frequently occurring members of Salkhan assemblage and it is characterised by the well developed colonial habit and by the size of component cells. Undifferentiated cells in the colony are difficult to make out the characters of individual cell, indicate the compactness of colony and amount of organic matter. This is further proved by the maceration techniques where they remain attached in spite of their being released from the rock matrix. P. vulgaris is quite similar to modern Chroococcacean cyanobacteria of the genus Anacystis.

Distribution: Palaeoproterozoic: the Kasegalik and McLeary Formations Belcher Supergroup, Canada; Mesoproterozoic: the Salkhan Limestone, Semri Group, Vindhyan Supergroup; Neoproterozoic: the Bitter Springs Formation, Australia.

Material: Several hundred specimens.

Type species: Palaeoanacystis minor, nov. sp.

Palaeoanacystis minor nov. sp.

(Figures 6f, 6h, 6j, 6l, 6n, 6o, 8a, 8b, 8d, 8e)

Diagnosis: Cells spheroidal to ellipsoidal, cells forming small aggregate of 16-32 cells, walls robust, smooth to psilate, seldom occurring solitary, enclosed in amorphous organic matter.

Etymology: With reference to the small size of the cells.

Type locality: Harna village, Rohtas District, Bihar.

Stratum typicum: Salkhan Limestone, India.

Type specimen: Figure $6 f$.

Description: Pluricellular aggregate of cells forming the compact small colonies, size of each colony ranges between 15 and $30 \mu \mathrm{m}$, average $20 \mu \mathrm{m}$ with 16-32 cells in each colony. Cells robust walled, small $2-3 \mu \mathrm{m}$ diameter (average $2.5 \mu \mathrm{m}, 25$ cells measured) and enclosed in amorphous organic matter. Reproduction by fission in three mutually perpendicular planes with the resulting daughter cells remaining attached to parent body. New colonies are formed by fragmentation.

Discussion: Palaeoanacystis minor is also a frequently occurring specimen in the Salkhan assemblage. They are found in abundance in the stromatolitic chert. P. minor has been noticed in the dark stromatolitic laminae, where Eoentophysalis form the base of laminae. No relationship in this order of occurrence could be established, but it seems that they are members of the same biotope occurring in Salkhan Limestone. Salkhan population of $P$. minor confirms in nearly all the salient features to generic diagnosis of Palaeoanacystis Schopf (1968) but differ in the size range and small colonial habit. It seems that fragmentation takes place at the early stage, so that the colony size remains small.

Distribution: Noted in the stromatolitic cherts of the Salkhan Limestone.

Material: A number of specimens are recorded in the Salkhan Limestone.

Genus: Sphaerophycus Schopf 1968

Type species: Sphaerophycus parvum Schopf 1968

Stratum typicum: Bitter Springs Formation, Australia.

\section{Sphaerophycus parvum Schopf 1968}

(Figure 5l)

Sphaerophycus parvum Schopf 1968, p. 672, Pl. 80, figures 4-10, table 4; Hofmann 1976, p. 1058, 1061, Pl. 2, figure 8?, Pl. 3, figures 1-6; Oehler 1977, P. 343, figure $12 \mathrm{H}$, I; Oehler 1978, p. 293, figure 10R, S; Horodyski and Donaldson 1980, p. 140, figures $5 \mathrm{~A}-\mathrm{E}, \mathrm{F}$ ?, G?, H?, I?, 6A, B; Horodyski and Donaldson 1983, figure 5A, B; Knoll 1982b, p. $783, \mathrm{Pl}$. 6, figures 3, 4; Hofmann and Jackson 1991 , p. 374, figures $8.9,8.10,8.11,10.1-10.3,11$ (Partim); Schopf 1992, p. 1070, Pl. 9, figure G, and p. 1097, Pl. 33, figure F; Kumar and Srivastava 1992c, p. 310, figure 8D; Kumar and Srivastava 1995, p. 107, figure 8L; Sergeev et al 1997, p. 222, figure 13A, C; Amrad and Bertrand-Sarfati 1997, p. 209, figure $7 \mathrm{G}$.

"Smaller Chroococcacean cyanobacteria" Mendelson and Schopf 1982, p. 71, Pl. 1, figure 11. Description: Cells, small spheroids to ellipsoidal, solitary or in pairs. Sometimes loosely associated, some specimens angulated, surface texture psilate.

\section{Figure 7 caption}

$\overleftarrow{\text { Figure 7. Microbial assemblage recorded from Salkhan Limestone of the Semri Group. (a-d) Sphaerophycus medium }}$ Horodyski and Donaldson, (a) (BSIP-10906; 34.6/104.3), (b) (BSIP-10905; 29.0/105.4), (c) (BSIP-13142; 47.6/107.5) (d) (BSIP-13142; 41.8/105.1). (e-g, l) Eosynechococcus grandis Hofmann, (e) (BSIP-13141; 50.5/106.4), (f) (BSIP-13139; 31.1/94.5), (g) (BSIP-10906; 37.8/99.8), (l) (BSIP-10907; 44.2/97.2). (h-k) Eosynechococcus moorei Hofmann, (h) (BSIP10906; 31.5/98.7), (i) (BSIP-13139; 42.2/94.8), (j) (BSIP-10907; 34.8/94.8), (k) (BSIP-10907; 44.2/97.2). (m) Myxococcoides minor Schopf (BSIP-10906; 28.8/99.5). Single scale bars $=10 \mu \mathrm{m}$; double bars $=50 \mu \mathrm{m}$. 


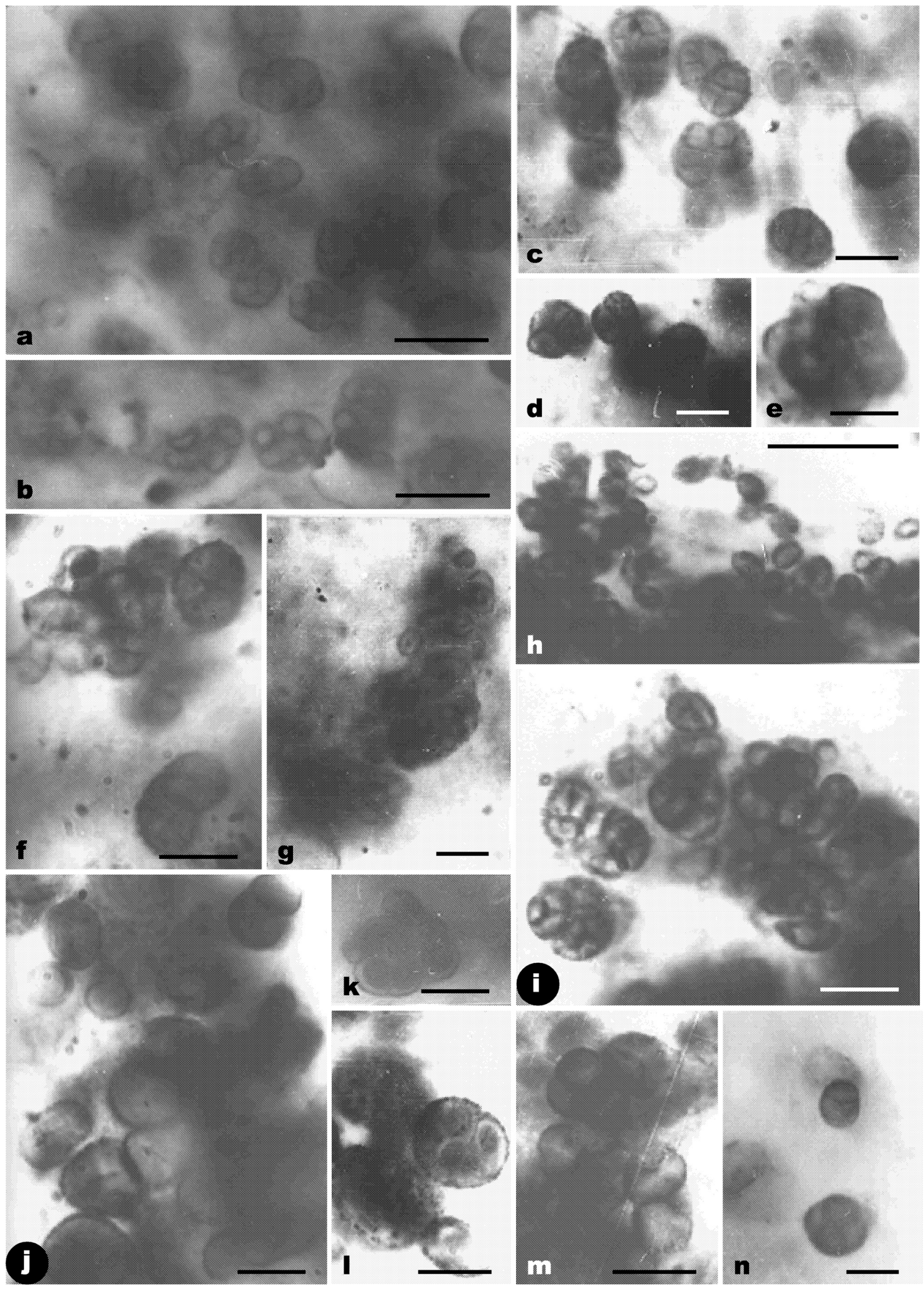

Figure 8. 
Cell diameter ranges between 2 and $3 \mu \mathrm{m}$ (average $2.5 \mu \mathrm{m} ; 25$ cells measured). Sheath encompassing cells present, typically hyaline, $0.4-0.5 \mu \mathrm{m}$ thick. Reproduction by fission. Daughter cells do not remain attached to the parent cell.

Discussion: The size of the Salkhan population overlaps with that of the type species in the Bitter Springs Formation. On the basis of their characteristic features like small size, shape their solitary/paired occurrence they are differentiated from Huroniospora psilata, Eosynechococcus isolatus, etc. Knoll (1982b) described S. wilsonii from Draken Conglomerate, Spitsbergen but subsequently on the suggestion of Hofmann put into S. medium (Knoll et al 1991).

Distribution: Palaeoproterozoic: Kasegalik and McLeary Formations Belcher Supergroup, Canada; Franceville Group, Gabon; Mesoproterozoic: Amelia Dolomite Formation, Australia; Balbirini Dolomite, McArthur Group, Australia; Dismal Lakes Group, Canada; Kheinjua Formation, Semri Group, India; Salkhan Limestone, Vindhyan Supergroup, India; Sukhaya Tunguska Formation, Siberia; Neoproterozoic: Draken Conglomerate, Spitsbergen; Bitter Springs Formation, Australia.

Material: Several hundred specimens.

Type species: Sphaerophycus medium Horodyski and Donaldson 1980

Stratum typicum: Dismal Lakes Group.

Sphaerophycus medium Horodyski and Donaldson 1980

(Figures 5j, 5k, 5m, 5n; figures 7a-7d)

Sphaerophycus medium Horodyski and Donaldson 1980, p. 140-141, figures 5J, K?, L?, M?, N?, O?, P?, 6C, 6D; Horodyski and Donaldson 1983, figures 5C, D?-H?; Green et al 1987, figure 5J, Knoll et al 1991, p. 553, figure 19.3; Schopf and Klein 1992, p. 9, figures F?-H?; Sergeev et al 1995, p. 27, figures 9.6-9.7; Kumar and Srivastava 1995, p. 107 , figures $8 \mathrm{M}, 12 \mathrm{~F}$.

Sphaerophycus wilsonii Knoll 1982b, p. 783, Pl. 9, figures 5-9.

Description: Cells sphaeroidal, $4-6 \mu \mathrm{m}$ in diameter (average $4.6 \mu \mathrm{m}$ total cells measured 100). Wall robust, $0.75 \mu \mathrm{m}$ granular to smooth, found in diad, tetrad or in linear clusters rare unicells. Cell division by binary fission, daughter cells are not attached with the parent cell.
Discussion: Sphaerophycus medium is abundant in the Salkhan population and are found in stromatolitic cherts and cherty stromatolites. These are randomly distributed in the amorphous organic matter. Their occurrence in diad, tetrad and linear clusters differentiates from the $S$. parvum. These are also distinguished by the slightly larger size. The diameter of both the species overlap somewhat as they do in Akademikerbreen Group of Svalbard (Horodyski and Donaldson 1983). As suggested by the Hofmann and Jackson (1991) S. wilsonii may be considered junior synonym of $S$. medium on the arguments put forth by them. But in our collection there are no solitary specimens as in Knoll's collection (1982b, figure 5) and are always found as diad and tetrad.

Distribution: Mesoproterozoic: the Dismal Lakes Group, Canada; Kotuikan and especially, Yusmastakh Formations, Northern Siberia; Kheinjua Formation, Semri Group, India; Neoproterozoic: the Draken Conglomerate Formation, Spitsbergen and the Limestone-Dolomite "Series", East Greenland. Material: A few hundred specimens.

Genus: Tetraphycus Oehler 1978

Type species: Tetraphycus hebeiensis Liu 1982

Stratum typicum: Wumishan Formation, China. Tetraphycus hebeiensis Liu 1982

(Figures 8c, 8h)

Tetraphycus hebeiensis Liu 1982, p. 152-153, Pl. 7, figures 1, 2, Pl. 8, figures 12, 13; Liu et al 1984, p. 179, Pl. 2, figures 9-11; Hofmann and Jackson 1991, p. 375-376, figures 10.7, 10.9-10.13.

Description: Solitary or clumped tetrads common. Compressed on one side. Cell dimension 5-7 $\mu \mathrm{m}$ long and $2-3 \mu \mathrm{m}$ wide (average $4.5 \times 2.6 \mu \mathrm{m}$; 100 cells measured) dark black in colour, no covering envelope noticed, diads, planar and cross tetrads are not noticed. Set in an amorphous organic matrix.

Discussion: Of the different species known, the present specimen compares with $T$. hebeiensis in all its salient diagnostic features described from Wumishan Formation, China (Liu 1982) with cells in the range of 5-8 $4 \mathrm{~m}$. It differs from Tetraphycus congregatus described from Kheinjua Formation (McMenamin et al 1983) which contain large number of cells forming colonies. It is possible that some of the specimens may be the earliest stages of $E$. belcherensis colonies.

\section{Figure 8 caption}

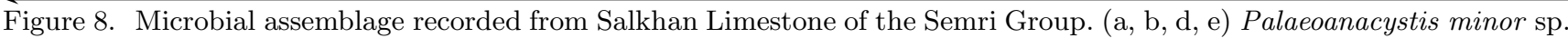
nov., (a) (BSIP-13141; 30.0/96.6), (b) (BSIP-13141; 37.2/99.5), (d) (BSIP-13142; 38.9/93.0), (e) (BSIP-10906; 34.6/104.3). (f, i, m, n,) Tetraphycus major Oehler, (f) (BSIP-10906; 32.5/98.3), (i) (BSIP-10906; 34.3/102.8), (m) (BSIP-13142; 49.7/106.5), (n) (BSIP-13143; 34.0/104.4). (c, h) Tetraphycus hebeiensis Liu, (c) (BSIP-10907; 35.0/103.4), (h) (BSIP10906; 34.3/102.8). (j-1) Eoentophysalis belcherensis Hofmann, (j) (BSIP-10906; 36.8/97.3), (k) (BSIP-10905; 32.4/105.0), (l) (BSIP-10907; 35.0/102.0). Single scale bars $=10 \mu \mathrm{m}$. 


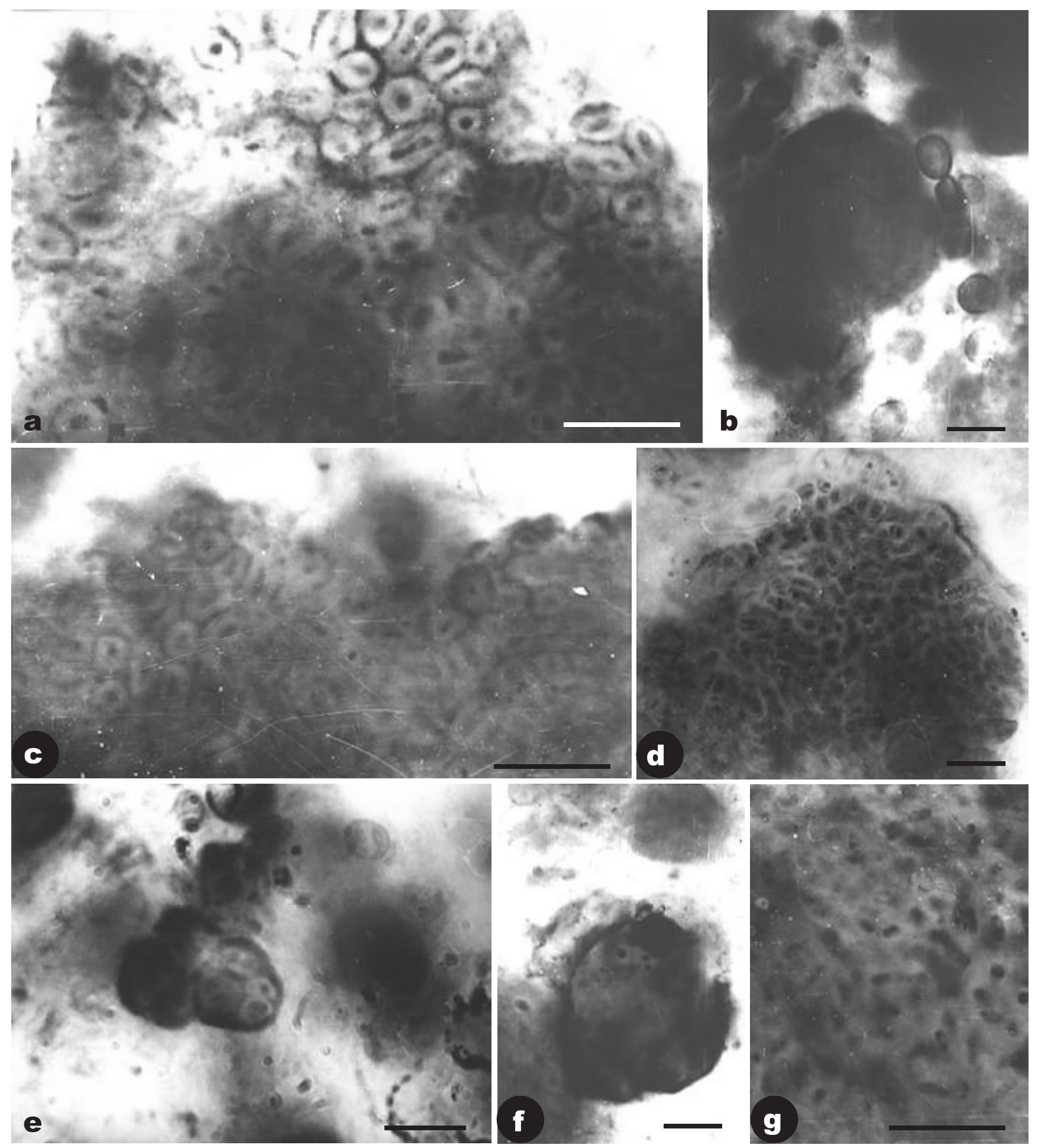

Figure 9. Microbial assemblage recorded from Salkhan Limestone of the Semri Group. (a-g) Eoentophysalis belcherensis Hofmann, (a) (BSIP-13142; 39.4/96.5), (b) (BSIP-13142; 42.3/96.5), (c) (BSIP-13142; 39.3/95.5), (d) (BSIP-13143; 32.4/105.0), (e) (BSIP-10906; 36.2/98.8), (f) (BSIP-13139; 38.8/95.0), (g) (BSIP-13142; 41.8/96.8). Single scale bars $=10 \mu \mathrm{m}$.

Distribution: Mesoproterozoic: Wumishan Formation, China; Uluksan Group, Bylot Supergroup, Canada.

Material: A few hundred specimens.
Type species: Tetraphycus major Oehler 1978 Stratum typicum: Balbirini Dolomite, McArthur Group, Australia.

Tetraphycus major Oehler 1978 


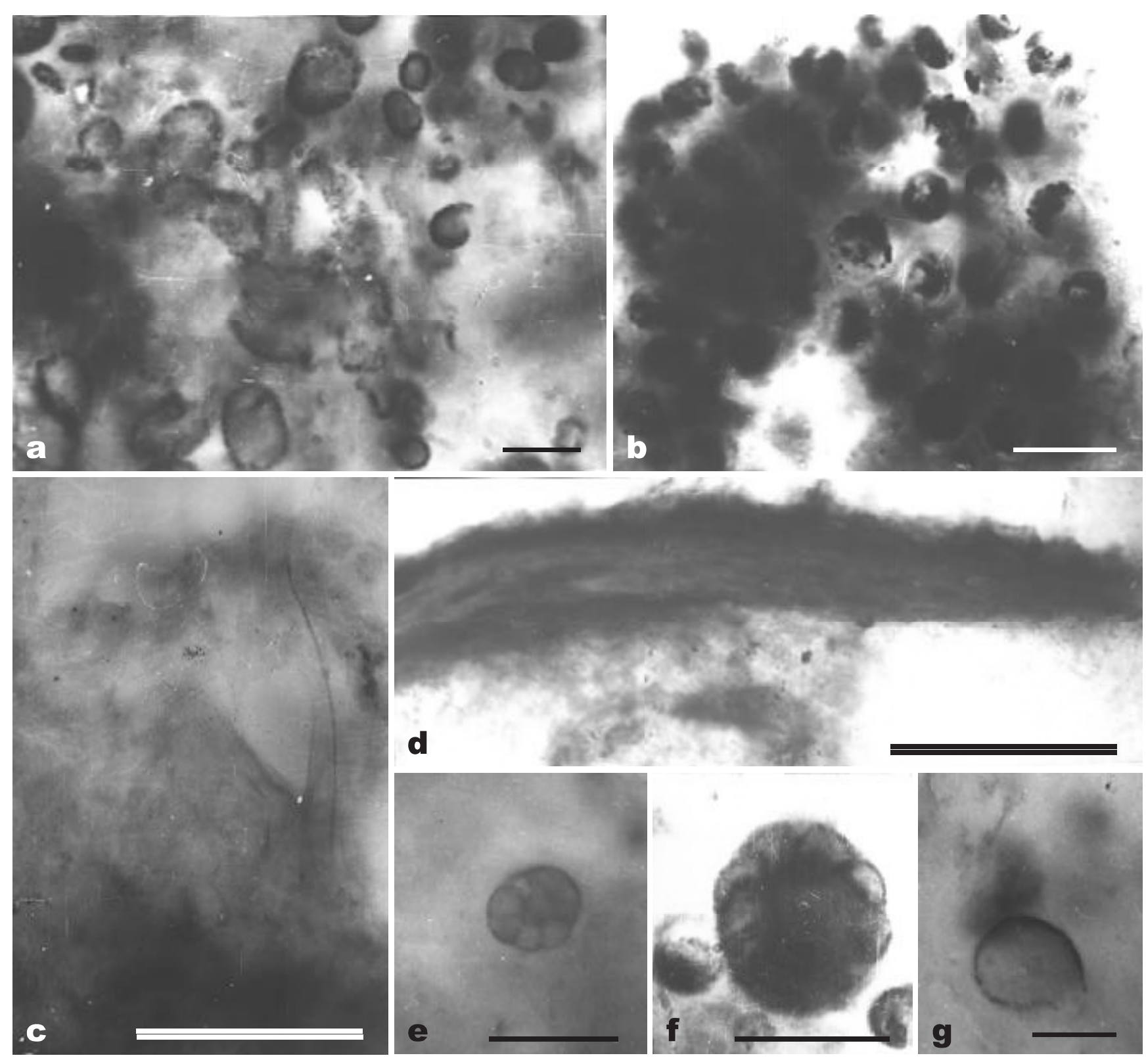

Figure 10. Microbial assemblage recorded from Salkhan Limestone of the Semri Group. (a, b) Huroniospora psilata Barghoorn, (a) (BSIP-10907; 34.7/94.7), (b) (BSIP-10907; 24.3/95.3). (c) Siphonophycus robustum Knoll et al (BSIP-10906; 37.1/95.3). (d) Eomicrocoleus crassus Horodyski and Donaldson (BSIP-10906; 36.1/108.4). (e, f) Conhemisphaera pendulua Luo and Wang, (e) (BSIP-13141; 37.4/97.7), (f) (BSIP-10907; 26.5/99.9). (g) Clonophycus ostiolum Oehler (BSIP-13141; $52.5 / 106.5)$. Single scale bars $=10 \mu \mathrm{m}$; double bars $=50 \mu \mathrm{m}$.

(Figures 8f, 8i, 8m, 8n)

Tetraphycus major Oehler 1978, p. 296, figures 10L-10Q; Kumar and Srivastava 1995, p. 107-108, figures $11 \mathrm{E}, 12 \mathrm{G}$

Description: Cells spheroidal to slightly polygonal due to compression. Cells diameter $3-5 \mu \mathrm{m}$ (average $3.4 \mu \mathrm{m}, 100$ cells measured). Cell walls psilate to granular, no cellular inclusion found. Cells commonly occur in planar tetrad, cross tetrad, diads and clusters of eight may be present. This mode of arrangement can be observed at one place or at different places, set within a common amorphous organic matrix.

Discussion: This species abundantly occurs in Salkhan bedded chert. It confirms in all salient features to the generic diagnosis of Oehler's (1978) specimens. Of at least 11 described species of Tetraphycus, distinguished chiefly on the basis of cell diameter, the present species compares with the T. major from the Balbirini Dolomite of McArthur Group, Australia (Oehler 1978) with the cells size in range of $2.2-5.0 \mu \mathrm{m}$ (with the average diameter 


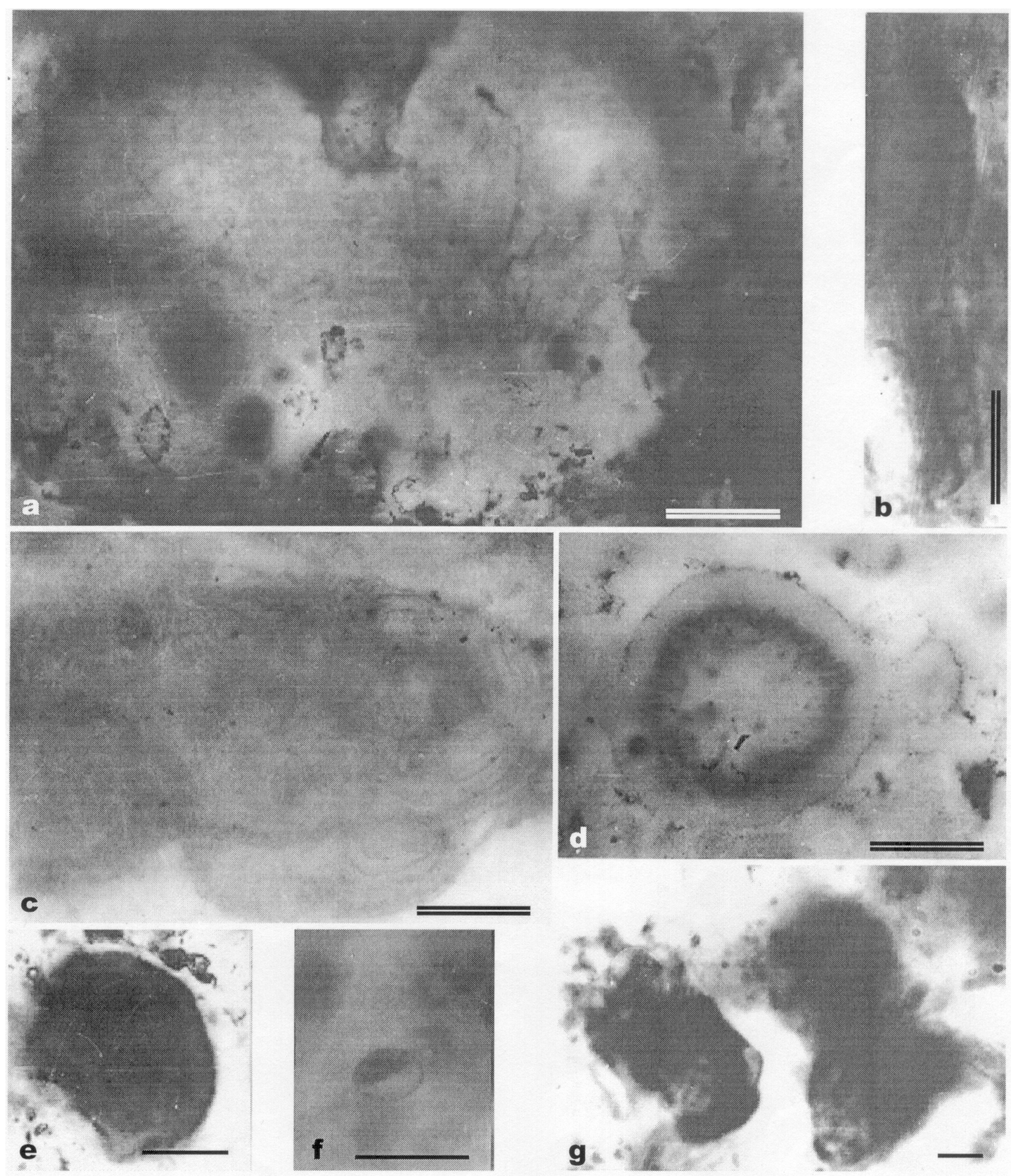

Figure 11. Microbial assemblage recorded from Salkhan Limestone of the Semri Group. (a) Unnamed Form F- (BSIP-13140; 41.6/105.6). (b) Unnamed Form E- (BSIP-10907; 40.0/106.0). (c) Unnamed Form C- (BSIP-10906; 37.9/104.0). (d) Unnamed Form A- (BSIP-13144; 37.8/109.5). (e) Clonophycus elegans Oehler (BSIP-13142; 40.2/98.0). (f) Clonophycus ostiolum Oehler (BSIP-13141; 35.8/99.3). (g) Unnamed Form D- (BSIP-10906; 38.2/102.0) Single scale bars $=10 \mu \mathrm{m}$; double bars $=50 \mu \mathrm{m}$.

$3.9 \mu \mathrm{m})$. The other species are either smaller or larger in size with the overlapping cell diameter but they do not have the average cell diameter, equal to that of T. major.
Distribution: Mesoproterozoic: the Kheinjua Formation, Semri Group, Vindhyan Supergroup, India; the Balbirini Dolomite, McArthur Group, Australia. 

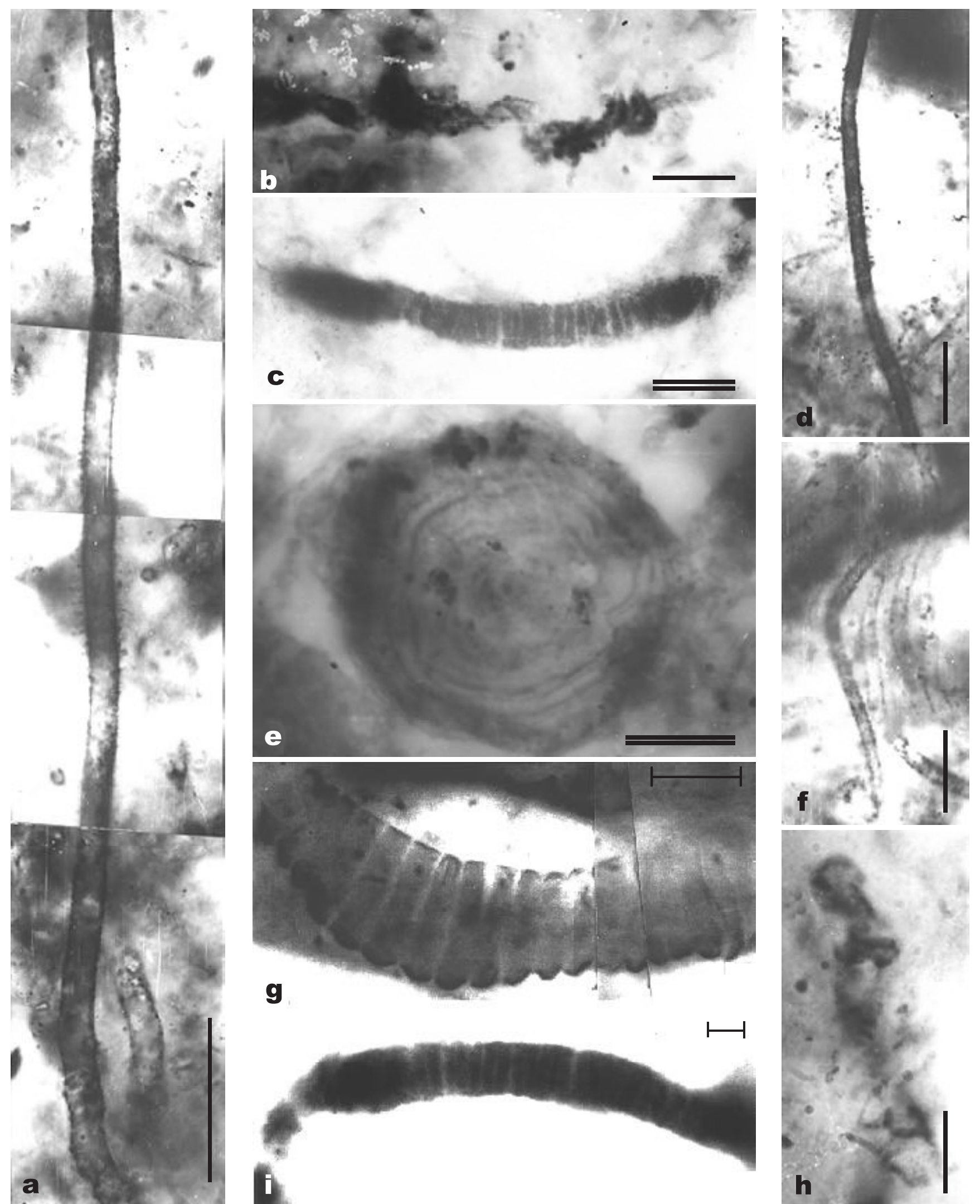

Figure 12. Microbial assemblage recorded from Salkhan Limestone of the Semri Group. (a, d, f) Siphonophycus robustum Knoll et al (a) (BSIP-13142; 26.7/100.6), (d) (BSIP-13142; 26.8/99.0), (f) (BSIP-13142; 27.0/100.5). (c) Oscillatoriopsis media Mendelson and Schopf (BSIP-10906; 38.1/98.5). (b, h) Siphonophycus septatum Knoll et al (b) (BSIP-10906; 33.5/99.4), (h) (BSIP-10906; 30.0/97.0). (e) Unnamed Form B- (BSIP-10906; 37.4/103.6). (g, i) Oscillatoriopsis longa Timofeev and Hermann, (g) (BSIP-10907; 43.2/98.8), (i) (BSIP-10906; 36.8/98.2). Single scale bars $=10 \mu \mathrm{m}$; double bars $=50 \mu \mathrm{m}$. 
Material: A few hundred cells.

Family: Eoentophysalidaceae Geitler 1932

Genus: Eoentophysalis Hofmann 1976 emend. Mendelson and Schopf 1982

Type species: Eoentophysalis belcherensis Hofmann 1976 emend. Mendelson and Schopf 1982

Stratum typicum: Kasegalik Formation, Canada.

Eoentophysalis belcherensis Hofmann 1976 emend. Mendelson and Schopf 1982.

(Figures 8j-8l; 9a-9g)

Eoentophysalis belcherensis Hofmann 1976, p. 1070,1072 , Pl. 4, figures 1-5, pl. 5, figures 3-6, pl. 6, figures 1-14;

Eoentophysalis cumulus Butterfield et al revised 1994.

Description: Cells polygonal, sphaeroidal, ellipsoidal, occur in solitary or in pairs, planar tetrads, irregular clusters and colonies, occasionally distorted due to mutual compression. The size of cells varies from $3-10 \mu \mathrm{m}$ across (with the average of $4 \mu \mathrm{m}, 100$ cells measured). Pleuricellular aggregate of cells forming the thick sheet. Dark stromatolitic laminae are formed by these cellular aggregates. Maximum length of sheet noticed is $800 \mu \mathrm{m}$ and breadth $200 \mu \mathrm{m}$. Generally $100-150 \mu \mathrm{m}$ long and $60-80 \mu \mathrm{m}$ broad sheets are noticed. Sometimes form pustulose laminae or palmelloid colonies. Dark-brown in colour. Sometimes dark black micron sized inclusions are present. Cells are enveloped by thin walls, which are sometimes weakly or darkly pigmented. Some of the enveloped double or paired ellipsoids contain spheroids (dark bleb of less than a micron size) as inclusion.

Discussion: Eoentophysalis belcherensis has been noted in stromatolitic chert. It occurs along the dark stromatolitic laminae pointing its role in the formation of stromatolite. These specimens are in conformity with the specimen described from the Kasegalik Formation of Canada both in generic and specific diagnosis. Yakschin (1990, 1991) described similar fossils from the Mesoproterozoic Kutungda Formation of Olenek Uplift as the new genera Eoxenococcus Yakschin and Corynophycus Yakschin. Sergeev in Sergeev et al (1995) interpreted the Kutungda population as E. belcherensis. Palaeoanancystis vulgaris Schopf 1968 (partim) described by Yakschin (1991, pl. VI, figures $3,5,6,8$, pl. VII, figure 6), Palaeoanancystis parvicellularis Yakschin (1991, pl. VI, figures 2, 4, 9), Tortiliphycus bifilamentosus Yakschin (1991, Pl. XV, figure 3), Phanerosphaerops tenuichalmis Yakschin (1991, Pl. III, figures 9, 11) are also placed in the synonymy list of E. belcherensis. Besides Myxococcoides minor Schopf (partim) Yakschin (1991, Pl. IX, figures 1, 2, 4, 5),
Archaeophycus venustus Wang et al 1983 (partim) Yakschin (1991, Pl. III, figure 10, Pl. VIII, figures 1, 6, Pl. IX, figure 3), Bulbiphycus sectilis Yakschin (1991, Pl. VIII, figure 2) are also considered as synonymy list of E. belcherensis. Entophysalis is commonly found in the regions, which are frequently exposed to atmosphere. The extensive mucilage helps them withstand harsh light and exposure. They regenerate as soon as the environment is favourable.

Distribution: Widely distributed in Palaeo- and Mesoproterozoic chert; much less abundant in Neoproterozoic assemblage.

Material: Several hundred colonies from the Salkhan Limestone.

Class: Hormogoneae Thuret 1875

Order: Oscillatoriales Elinkin 1949

Family: Oscillatoriaceae (Gray) Kirchner 1898

Genus: Oscillatoriopsis Schopf 1968 emend. Mendelson and Schopf 1982 emend. Butterfield (in Butterfield et al 1994)

Type species: Oscillatoriopsis media Mendelson and Schopf 1982

Stratum typicum: Sukhaya Tunguska Formation, Russia.

Oscillatoriopsis media Mendelson and Schopf 1982

(Figure 12c)

Oscillatoriopsis media Mendelson and Schopf 1982, p. 64-65, pl. 4, figures 3, 5, 6; Ogurtsova and Sergeev 1987, pl. 9, figures 1, 2; Sergeev 1992, p. $87-88$, pl. 26 , figure 4 , pl. 27, figures 1, 2; Schopf 1992, pl. 10, figures F, H; Sharma and Sergeev 2004, figures 5E, 7D.

Description: Trichomes multicellular, uniseriate, unbranched, not constricted at the septa. Cross wall distinct, not granular, sheath absent. Trichomes solitary, slightly curved near the apices. Trichomes are $70-100 \mu \mathrm{m}$ long. Medial cells of trichomes short, cylindrical, approximately rectangular. 2-3 $\mu \mathrm{m}$ long and $10-12 \mu \mathrm{m}$ wide, with average dimension of $2.5 \times 10.7 \mu \mathrm{m}$ (30 cells measured in the two trichomes). Structural features could not be observed near the apices due to amorphous organic matter. Reproductive structures unknown. Discussion: The genus Oscillatoriopsis was erected by Schopf (1968) to include the sheathless trichomes of oscillatoriacean cyanobacteria similar to modern genus Oscillatoria Vaucher. Later, Mendelson and Schopf (1982) emended it to include all Oscillatoria or Lyngbya-like trichomes encompassed by a sheath less than $1 \mu \mathrm{m}$ thick. Subsequently, Butterfield (in Butterfield et al 1994) emended this genus to include unbranched, uniseriate, cellular trichomes with cell length less or equal to cell diameter. Sergeev (2001), however, 
did not agree to this proposal. In general morphology Oscillatoriopsis is similar to all the characters to Oscillatoriopsis media described by Mendelson and Schopf (1982) except that Salkhan specimens are larger and thicker in size. Only two trichomes of Oscillatoriopsis media have been reported one each in stromatolitic chert and cherty stromatolites. These are comparable to several extant Oscillatoriacean species. Lack of constriction at the septa and nature of apices are distinctive of Oscillatoriopsis media.

Distribution: Widely distributed in Proterozoic cherts and organic walled assemblages. MesoNeoproterozoic Sukhaya Tunguska Formation, Russia; Salkhan Limestone, Semri Group, India.

Material: Only two trichomes.

Type species: Oscillatoriopsis longa Timofeev and German 1979, emend. Butterfield (in Butterfield et al 1994)

Stratum typicum: Lakhanda Formation, Russia. Oscillatoriopsis longa

(Figures 12g, 12i)

Unnamed microfossil Zhang Z 1981a, p. 793, figure 3a.

Doushantuonema peatii Zhang Z 1981b, p. 204, pl. 1a-c; Zhang Z 1982, p. 1255, pl. 1, figure 5 .

Palaeolyngbya sp., Zhang Z 1982, p. 1225, pl. 1, figure 12 .

Hyalothecopsis nanshanensis Zhang P 1982, pp. 35-36, pl. 1, figure 2.

Hyalothecopsis sinica Zhang P 1982, pp. 35, 39, pl. 1, figure 1 .

Oscillatoriopsis major Liu 1982, p. 139, pl. 29, figures 3,4 .

Halythrix leningradica Schenfil 1983, p. 473, pl. 1, figure 1.

Oscillatoriopsis variabilis Strother et al 1983, p. 26, pl. 3, figures 3-6, 11 .

Oscillatoriopsis princeps Zhang and Yan 1984, pp. 198, 203, pl. 1, figure 6 .

Oscillatoriopsis aculeata Zhang and Yan 1984, pp. 199, 203, pl. 1, figure 7 .

Oscillatoriopsis maxima (Zhang Y) Zhang Z (1986), p. 83, pl. 2, figure 3.

Oscillatoriopsis connectens Zhang and Gu 1986, pp. 323-324, 329, pl. 1, figure 10.

Oscillatoriopsis strictura Zhang and $\mathrm{Gu}$ 1986, pp. 324, 329-330, pl. 1, figure 8.

Oscillatoriopsis valida Zhang and $\mathrm{Gu}$ 1986, pp. 324, 330, pl. 1, figure 9 .

Oscillatoriopsis planaris Zhang and Gu 1986, pp. 324, 330, pl. 1, figure 12 .

Partitiofilum tungusum Jankauskas et al 1989, p. 118, pl. 27, figure 4 .

Filiconstrictosus magnus, Yakschin 1991, pp. 32-33, pl. 11, figure 2 .
Description: Trichomes multicellular, uniseriate, unbranched, not constricted at the septa. Cross wall distinct, not granular, sheath absent. Trichomes solitary, slightly curved near the apices. Trichomes are $\sim 80 \mu \mathrm{m}$ long. Medial cells of trichomes short, cylindrical, approximately rectangular. 2-3 $\mu \mathrm{m}$ long and $13-14 \mu \mathrm{m}$ wide, with average dimension of $2.5 \times 10.7 \mu \mathrm{m}$ (30 cells measured in the two trichomes). Reproductive structures unknown.

Discussion: In a major restudy, Butterfield et al (1994) merged many species of Oscillatoriopsis to include only those filamentous microfossils that can be confidently identified as cellular trichomes, lack enveloping sheath and have a cell length: width ratio less than or equal to 1 . More than 75 species of Oscillatoriopsis have been considered and 54 have been put as synonymy or merged with one or the other species. It has been noted that all the species are known from unique or few specimens and derived from few localized assemblages. They recognized four basic species of Oscillatoriopsis with diameter less than $25 \mu \mathrm{m}$ : O. vermiformis, 1-3 $\mu \mathrm{m}$ wide; $O$. obtusa, 3-8 $\mu \mathrm{m}$ wide; $O$. amadeus 8-14 $\mu \mathrm{m}$ wide and $O$. longa $14-25 \mu \mathrm{m}$.

Distribution: Mesoproterozoic: Salkhan Limestone, Semri Group, India; Neoproterozoic: Lakhanda Formation, Russia; Doushantuo Formation, China.

Material: Two specimens in Salkhan Limestone.

Genus: Eomicrocoleus Horodyski and Donaldson 1980

Type species: Eomicrocoleus crassus Horodyski and Donaldson 1980

Stratum typicum: Dismal Lakes Group, Arctic Canada.

Eomicrocoleus crassus Horodyski and

Donaldson 1980

(Figure 10d)

Eomicrocoleus crassus Horodyski and Donaldson 1980, p. 154, figure 15A, 15B; Sergeev 2001, p. 442, figure 9.5 .

Description: Multilamellated trichomes are common component of Salkhan population. These are $3 \mu \mathrm{m}$ broad and $40-60 \mu \mathrm{m}$ long sheaths. Bundles are constituted of 20-30 such sheaths. Dark brown in colour. Set in the organic matrix. These bundles are generally underlain by the coccoid cyanobacteria.

Discussion: Occurrence of such bundles of sheath in bedded chert and stromatolitic chert of Salkhan assemblage in the areas where degraded organic matter is present in plenty suggests that these are remnants of cyanobacterial sheath. Since no cellular remains are observed in bundles, affinity of these sheaths could not be established. Seong-Joo and Golubic (1998) have interpreted 
these remains as polytrichomatous cyanobacterial filaments, comparable to species of the modern genera Microcoleus, Hydrocoleum and Schizothrix. Specimens without common envelope are assigned to Polythrichoides German but some specimens with sheaths have been referred to this genus (Jankauskas 1982, pl. 48, figure 16). Hofmann and Jackson (1991) opined that Eomicrocoleus may thus be a junior synonym of Polythrichoides.

Distribution: Widely distributed in Proterozoic chert assemblages.

Material: A dozen preserved filaments have been noted in Salkhan Limestone.

Order: Nostocales? or Oscillatoriales

Genus: Siphonophycus, Schopf 1968 emend. Knoll and Golubic 1979, emend. Knoll et al 1991

Type species: Siphonophycus robustum (Schopf 1968) comb. nov. Knoll et al 1991, emend. Butterfield (in Butterfield et al 1994)

Stratum typicum: Bitter Springs Formation, Australia.

Siphonophycus robustum Knoll et al 1991.

(Figure 10c; figures 12a, 12d, 12f)

Eomycetopsis robusta Schopf 1968, p. 685, pl. 82, figures 2, 3, pl. 83, figures 1-4; Knoll and Golubic 1979, p. 149, figure 4A, B; Mendelson and Schopf 1982, 59, 60, 62, pl. 1, figures 9, 10; in Zhang Z 1982 , p. 1254 , pl. 1 , figures 8 , 11; Zhang Z 1984, p. 138, pl. 2, figure 10; Sergeev 1984, p. 436, figure 2a-2r; Cao 1985, p. 186, pl. 1, figure 4a, b; Golovenok and Belova 1993, pl. 2, figure e.

Eomycetopsis filiformis Schopf 1968, p. 685, 686, pl. 82, figure 1, 4, pl. 83, figures 5-8.

Eomycetopsis ex gr. obtusa Yakschin 1991, p. 36, pl. XII, figure 4.

Eomycetopsis spp. (partim) Mendelson and Schopf 1982, p. 62, pl. 4, figure 2.

Rhicnonema antiquium Hofmann, in Zhang Z 1982, p. 1255, pl. 1, figure 1; in Zhang Z 1984, p. 138, pl. 1, figure 1 .

Cyanonema attenuata (partim) Yakschin 1991, p. 36 , pl. XII, figure 1.

Empty algal tubes Schenfil 1983, p. 471, figure 1.4, 1.5 .

Siphonophycus robustum Knoll et al 1991, p. 565, figure 10.3, 10.5; Sergeev 1994, p. 250-251, figure $8 \mathrm{~F}$; Kumar and Srivastava 1995, p. 114, figure 14C; Sergeev et al 1997, p. 230, figure 14A; Zhang et al 1998, p. 22, figure 4.11; Srivastava and Kumar 2003, p. 26, pl. 7.2, pl. 10.10.

Description: Filaments tubular, curved, unbranched non-septate, more than $100 \mu \mathrm{m}$ long (incomplete). Surface is smooth to finely granular due to diagenetic effect, occur solitary or interwoven, forming mat. Width $3-4.5 \mu \mathrm{m}$ (average $3.7 \mu \mathrm{m}, 50$ specimens measured). Dense masses of filaments align parallel or perpendicular to bedding lamination.

Discussion: Siphonophycus is the predominantly mat forming microbe in many Proterozoic benthic assemblages, sometimes occurs solitarily. This species is common in stromatolitic cherts and cherty stromatolites of Salkhan Limestone. The sheaths may occur vertically or parallel to the lamination. Tubes of Siphonophycus robustum are considered as empty cyanobacterial (oscillatoriacean or nostocacean) sheaths (Knoll and Golubic 1979; Mendelson and Schopf 1982; Knoll et al 1991). Knoll et al (1991) discussed the genus Siphonophycus described from Bitter Springs Formation, Australia and after the study of three form genera viz. Siphonophycus kestron, Eomycetopsis robusta and Tenuofilum septatum placed them in synonymy as $S$. kestron, $S$. robustum, S. septatum. Earlier Pjatiletov (1988) synonymized Leiothrichoides German (1974) with Eomycetopsis that was later put under the Siphonophycus by Knoll et al (1991). They further argued that the larger populations of the Siphonophycus are presumably cyanobacterial, but $S$. septatum and S. robustum could be flexi-bacterial in origin (Aizenshtat et al 1984). Many cyanobacterial species could have similar morphology and some may assume this morphology taphonomically. Zhang et al (1998) therefore proposed that the taxonomy of the microbial sheath is a form taxonomy.

Distribution: Widely distributed in Proterozoic cherts, and Phanerozoic deposits and organic walled assemblages.

Material: A few hundred specimens.

Type species: Siphonophycus septatum Knoll et al 1991

Stratum typicum: Bitter Springs Formation, Australia.

\section{Siphonophycus septatum Knoll et al 1991}

(Figures 12b, 12h)

Tenuofilum septatum Schopf 1968, p. 679, pl. 86, figures 10-12; not Tenuofilum septatum Schopf, Schopf and Blacic, 1971, pl. 108, figures 11, 13.

Archaeotrichion contortum Schopf 1968, p. 686, Pl. 86, figures 1-2; Wang et al 1983, p. 170, figures 8, 4-8.

Eomycetopsis campylomitus Lo 1980, pp. 143-144, pl. 1, figures 9-11.

Allachjunica tenuiuscula Kolosov 1982, p. 80, pl. 14, figure 1.

Judomophyton microscopiocum Kolosov 1982, p. 75 , pl. 11, figure 1 .

Siphonophycus chuii Liu 1982, p. 148, pl. 11, figure $5,8,11$.

Eophormidium capitatum Xu 1984, pp. 219, 314, p. 1 , figure 5 . 
Archaeotrichion lacerum Jankauskas et al 1989, p. 88 , pl. 39, figures $4 \mathrm{a}-\mathrm{b}$.

Siphonophycus septatum Knoll et al 1991, p. 565, figure 10.2; Kumar and Srivastava 1995, p. 114115 , figure $14 \mathrm{D}$.

Description: Fine thread like filament, sinuously wounded, non-septate, unbranched and more or less uniform in diameter, commonly $1 / 2 \mu \mathrm{m} \sim 1 \mu \mathrm{m}$ broad and $80 \mu \mathrm{m}$ or large in length. They are composed of dark brown organic matter. Occur solitary or in groups, sometimes broken into segments tens of microns long.

Discussion: Sharma (1993) described Archaeotrichion contortum from Salkhan Limestone. Filaments compare well with the Australian specimens $(1 / 2-2 / 3 \mu \mathrm{m}$, mean $<1 \mu \mathrm{m})$. Morphological features are similar to the Archaeotrichion, Eomycetopsis and Siphonophycus. As discussed above, Knoll et al (1991) merged Eomycetopsis into Siphonophycus. Subsequently, Butterfield (in Butterfield et al 1994) put the Archaeotrichion contortum as junior synonymy of Siphonophycus septatum. Therefore the Archaeotrichion contortum described by Sharma (1993) has been placed as Siphonophycus kestron. The smaller size diameter and non-septate nature suggest their bacterial affinity.

Distribution: Widely distributed in Proterozoic and Phanerozoic deposits.

Material: Several specimens.

Order: Insertae sedis

Family: Insertae sedis

Genus: Huroniospora Barghoorn 1965 in Barghoorn and Tyler 1965, p. 563-577, pl. 2, figure 5.

Type species: Huroniospora psilata, Barghoorn 1965, in Barghoorn and Tyler 1965

Stratum typicum: Gunflint Iron Formation, Canada.

Huroniospora psilata Barghoorn 1965, in Barghoorn and Tyler 1965

(Figures 10a, 10b).

Huroniospora psilata Barghoorn 1965, in Barghoorn and Tyler 1965, Kumar and Srivastava 1992c, p. 304, figure 8I.

Description: Cells sphaeroidal to ellipsoidal, occur solitary and loosely in the assemblage. No envelope or mucilage covering noticed. Walls granular to psilate. Some of the specimens show smooth margin. The size range of cells $3-7 \mu \mathrm{m}$ with an average of $3-4 \mu \mathrm{m}$.

Discussion: These cells are found in bedded chert and stromatolitic chert of the Salkhan population and often confined to areas where no other biota occur. They are often set in a matrix of amorphous organic matter, which may represent uncrushed remains of mucilage. Intracellular dense mass is absent. The Salkhan population confirms in all the salient features with the specimens described by Barghoorn and Tyler (1965). Cells generally occur in the area where no other member of the Salkhan population is found.

Distribution: Most of the Proterozoic cherts of the world.

Material: A few dozen specimens.

Genus: Conhemisphaera Luo and Wang in Luo et al 1983

Type species: Conhemisphaera pendulua Luo and Wang in Luo et al 1983

Stratum typicum: Not mentioned (Chinese publication) in english version.

Conhemisphaera pendulua Luo and Wang in Luo et al 1983

(Figures 10e, 10f)

Conhemisphaera pendulua; Luo et al 1983, p. 38, Pl. II, figures 7,8 .

Description: Spherical colonies composed of more than ten hemispherical cells arranged loosely on the periphery of thick colonial envelope. Individual cells are without sheath. The diameter of the colony ranges from $20-25 \mu \mathrm{m}$ (average $23 \mu \mathrm{m}, 25$ colonies measured). Peripheral cells are ellipsoidal, sometimes overlapping each other; $2-3 \mu \mathrm{m}$ long and $1.4 \mu \mathrm{m}$ broad. Central portion of the colony is hollow.

Discussion: It is an enigmatic form recorded in the stromatolitic chert of Salkhan population. The typical arrangement of cells and their association with cyanobacterial elements indicate their cyanobacterial affinity. It could as well be a preservational feature. A colonial form may assume such shape if it is present in a plane parallel to the grinding surface. The other possibility is that a Volvox like algal ball (not the Volvox) cut in any plane may assume such morphology. It is difficult to assess the nature of this microorganism at present.

Distribution: Mesoproterozoic: Found in the Salkhan Limestone; Neoproterozoic: (Uppermost Sinian-lowermost Cambrian age microfossils) from Qingshen-Zhijin County, Guizhou Province, China. Material: About two dozens specimens recorded.

Genus: Clonophycus Oehler 1977 emended D Z Oehler 1978

Type species: Clonophycus elegans Oehler 1977 Stratum typicum: H. Y. C. Pyritic Shale Member of Barney Creek Formation (McArthur Group), Australia.

Clonophycus elegans Oehler 1977

(Figure 11e)

Clonophycus elegans: Oehler 1977, p. 346, figure 11A-D, J, K. emended Oehler 1978 
Description: Cells spheroidal to ellipsoidal, sometimes adpressed by mutual compression of cells, cells thin walled, smooth to granular, generally single walled, may be double layered. Cells are densely packed within a thin walled sac of $25-30 \mu \mathrm{m}$ diameters. Number of cells varies in each sac but generally in multiples of two. Internal cells are released through the opening on the margin, it may be rounded to slit/cleavage like, sometimes a small dot of black coloured matter is noticed on the cells which may be less than $1 \mu \mathrm{m}$ in size.

Discussion: Clonophycus elegans is a distinct micro-organism and is confined to only stromatolitic cherts. C. elegans and other four species C. biattina, $C$. ostiolum, $C$. refringens and C. vulgaris are known from Balbirini Dolomites (McArthur Group) of Australia. A single species C. elegans has been recorded from the $\mathrm{H}$. Y. C. Pyritic Shale. The pattern of rupture and association of cells in an enclosed sheath indicate that this fossil could be a sporangium. It is not determined whether the specimens belong to prokaryote or eukaryote. In both the algae breaking pattern of sporangia is similar (Fritsch 1935, 1945; Starr 1955). Possibly Clonophycus is Gloecapsoid colonies of Eoentophysalis or Gloeocapsa.

Distribution: Mesoproterozoic cherts of Australia and India.

Material: About ten specimens.

\section{Type species: Clonophycus ostiolum D Z Oehler} 1978

Stratum typicum: Balbirini Dolomite, Australia. Clonophycus ostiolum Oehler 1978

(Figure 10g; Figure 11f)

Clonophycus ostiolum Oehler 1978, p. 303, figures $4 \mathrm{R}-4 \mathrm{~T}$.

Description: Cells spheroidal, thin walled and pressed due to mutual compression enclosed in a sac-like body (or sporangia) spheroids range in size from $6-15 \mu \mathrm{m}$ in diameter (average $10 \mu \mathrm{m} ; 25$ cells measured), smooth walled, characterized by a large opening on one side, rounded opening or ruptured wall 5-7 $\mu \mathrm{m}$ through which spores or cells are released. Individual cells are $2-3 \mu \mathrm{m}$ (average $2.75 \mu \mathrm{m}, 10$ cells measured) finely to coarsely granular. No sheath and black inclusion observed.

Discussion: Tightly clustered cells encapsulated in a sac like body give an impression of sporangia. The pattern of rupture and release of cells suggest that the cells may belong to prokaryote/eukaryote since the manner of dispersal of cells is same in both. The specimen $C$. ostiolum was reported from Balbirini Dolomite and interpreted to be sporangia like body considering that sporangia commonly break open in this manner (Fritsch 1935, 1945; Starr 1955).
Distribution: Mesoproterozoic cherts of Australia and India.

Material: About ten specimens.

\section{Unnamed Form A}

(Figure 11d)

Description: Solitary double walled spheroidal specimen with knuckle shaped protuberance, which has continuous outer wall with parent body. Several fine villi like protruding structures are noticed on the inner wall. Outer wall granular, inner wall robust. The outer diameter of sphaeroidal structure is $40 \mu \mathrm{m}$ whereas the inner diameter is $30 \mu \mathrm{m}$. Discussion: It is a rare specimen in the Salkhan assemblage found in bedded chert. A spheroid of such a dimension with knuckle shaped protuberance has not been recorded anywhere. Since it occurs in the cyanobacteria dominant assemblage it may be accorded a cyanobacterial affinity but not kept in any group and presently placed in Incertae sedis. It is probable that these may represent isolated instances of smooth walled akinetes bereft of vegetative cells. "Probably it is a homocystous anabenoid alga".

\section{Unnamed Form B}

(Figure 12e)

Description: Multilamellated sphaeroidal sheaths. Solitary, occurring freely. Diameter of sphaeroidal structure $200 \mu \mathrm{m}$. Each enveloping sheath is $2-3 \mu \mathrm{m}$ thick, light brown in colour, robust. Outermost sheath is made-up of diffused organic matter. Subsequent inner sheaths are psilate to granular.

Discussion: This specimen is found in the bedded cherts of Salkhan Limestone. Due to its association with microbial assemblage of cyanobacterial affinity these are considered produce of cyanobacteria. Since there are no cells inside to distinguish or characterise, it is difficult to understand to which specific species this sheath genera belongs. Its large size indicates that some larger colonial forms were in existence in the Salkan population. It is also possible that it may be a degradation feature of amorphous organic matter/precipitate pattern.

\section{Unnamed Form C}

(Figure 11c)

Description: Multilamellated bilobate sheath. Solitary specimen occurring freely. It is an extraordinary large size specimen - $800 \mu \mathrm{m}$ long and $200 \mu \mathrm{m}$ broad. Curvature in the middle part leads to form bilobate structure. 5-7 layers of successive covering forms this specimen. Outer wall diffuse while the inner walls are psilate to granular and light brown in colour.

Discussion: Solitary specimen is found in Salkhan bedded chert. Its association with microbial 
assemblage of cyanobacterial affinity is considered akin to cyanobacteria. It is also possible that the specimen may be only a degradation feature of amorphous organic matter, since sheath genera of cyanobacteria of such dimension are not known; it is placed under unnamed category.

\section{Unnamed Form D}

(Figure 11g)

Description: Ellipsoidal to polygonal organic mass. Dark black in colour. $15 \mu \mathrm{m}$ long to $20 \mu \mathrm{m}$ wide, outer texture granular. No internal structure observed.

Discussion: This is a rare component of bedded and stromatolitic chert. Probably formed by the degraded mucilaginous sheaths of encompassing coccoidal cells. No definite mode of origin can be assigned to these structures.

\section{Unnamed Form E}

\section{(Figure 11b)}

Description: Uniseriate, unbranched, slightly constricted at the septa, gradually tapering, length of the filament $15 \mu \mathrm{m}$, individual cell demarcation at $2 \mu \mathrm{m}$ interval. No cells are observed, their impression only noticed on the sheaths.

Discussion: This form occurs in bedded chert and stromatolitic chert. Rare occurrence of this form does not allow any meaningful interpretation except that it is a microbial component of Salkhan population.

\section{Unnamed Form F}

\section{(Figure 11a)}

Description: Extraordinary large bilobate structure composed of fine radial fabric in the centre. Outer wall/sheath is robust, granular $3 \mu \mathrm{m}$ thick, dark brown in colour, central portion hyaline. Set in amorphous organic matrix, $1500-2000 \mu \mathrm{m}$ long and $850 \mu \mathrm{m}$ broad.

Discussion: These are found in the bedded and stromatolitic chert. Such large structured sheath may be degraded organic mass of sheaths left by the extra large Chroococcacean colony. No other meaningful information obtained by the study of these sheaths.

\section{Acknowledgements}

The author is thankful to Dr. Jyotiranjan S Ray and Prof. Chandan Chakraborty for the invitation to contribute a paper to the special volume on Vindhyans. The paper has benefited from the comments on earlier version of the manuscript by Drs. B S Venkatachala, Manoj Shukla, V N Sergeev, Meera Tiwari and two anonymous referees. Dr N C Mehrotra, Director BSIP, kindly permitted to publish this paper. I am grateful to my friends Mr. V K Yadav and Mr. Rajendra Bansal for accompanying me in the field. Mr. Madhavendra Singh helped in preparing the plates.

\section{References}

Ahmad F 1962 The origin and significance of the Vindhyan Scarp; Proc. 2nd Symp. Earthquake Engg. Univ. Roorkee, pp. 513-525.

Aizenshtat Z G, Lipiner G and Cohen Y 1984 Biogeochemistry of Carbon and Sulfur in the microbial mats of the Solar Lake (Sinai); In: "Microbial mats: Stromatolites" (eds) Cohen Y, Castenholz R W and Halvorson Alan R. Liss, New York.

Amard B and Bertrand-Sarfati J 1997 Microfossils in 2000 Ma old cherty stromatolites of the France-Ville Group, Gabon; Precamb. Res. 81 197-221.

Anbarasu K 2001 Acritarch from Mesoproterozoic Chitrakoot Formation, Semri Group, Chitrakoot area, Central India; J. Geol. Soc. India 57 179-183.

Auden J B 1933 Vindhyan sedimentation in the Son Valley, Mirzapur district; Geol. Surv. India Memoir 62 141-250.

Azmi R J 1998 Discovery of Lower Cambrian small shelly Fossils and Brachiopods from the Lower Vindhyan of Son Valley, Central India; J. Geol. Soc. India 52 381-389.

Balasubrahmanyan M N and Chandy K C 1976 Lead isotopes studies of galena from some occurrences in India; Rec. Geol. Surv. India 107 141-148.

Barghoorn E S and Tyler S A 1965 Microorganism from the Gunflint chert; Science 147 563-577.

Beer E J 1919 Note on spiral impression on Lower Vindhyan Limestone; Rec. Geol. Surv. India 50109.

Bhattacharyya A 1996 Foreword; In: Recent Advances in Vindhyan Geology (ed.) Bhattacharyya A, III-VIII.

Butterfield N J, Knoll A H and Swett K 1994 Paleobiology of the Neoproterozoic Svanbergfjellet Formation, Spitsbergen; Fossil and Strata 34 1-84.

Cao Fang 1985 The new data of algal microfossils from the Sinian Doushantuo Formation; Bull. Tianjin Instt. Geol. Min. Resources 12 183-193.

Chakrabarty A 2001 Are meandering structures found in Proterozoic Rocks of different ages of the Vindhyan Supergroup of Central India biogenic?: a scrutiny; Ichnos 8 131-139.

Cloud P, Moorman M and Pierce D 1975 Sporulation and ultrastructure in a Late Proterozoic Cyanophyte: Some implication for taxonomy and plant phylogeny; Quart. Rev. Biol. 50 131-150.

Crawford A R and Compston W 1970 The age of the Vindhyan System of Peninsular India; Quart. J. Geol. Soc. London 125 351-371.

Das Gupta S 1997 Lithostratigraphy and geochemical studies of limestone formations of Rohtas Subgroup in Bhiar; Indian Min. 51 77-90.

Drouet F 1968 Revision of classification of the Oscillatoriaceae; Acad. Nat. Sci. Philad Monograph 15 370pp.

Elinkin A A 1949 Monographie algarum Cyanophycearum aquidulcium et terrestrium infinibus URSS inventarum; Izdetelstvo Akademii Nauk SSSR, Moscow, Pars specialis (Systematica) Fascicle II 985-1908.

Fogg G E, Stewart W D P, Fay P and Walsby A E 1973 The blue green algae (London: Academic Press), pp 459.

Fritch F E 1935 Structure and Reproduction of the Algae; 1 (New York: Macmillan Studies), p. 791. 
Fritch F E 1945 Structure and Reproduction of the Algae; 2 (London: Cambridge University Press), p. 939.

Geitler L 1932 Cyanophyceae Rabenhorst's KryptogamenFlora; Akademie Verlagsgesellschaft, Leipzig, Band 14, 1196pp.

German T 1974 Nakhodi massevikh skoplyennii trikhomov V. Rifeyi ii microphytofossilii Proterozya i Rannoyogo Palaeozoa SSSR: 6-10 (The discovery of massive accumulations of trichomes in Riphean; microphytofossils of Proterozoic and Lower Paleozoic SSSR); 6-10.

Golovenok V K and Belova M Yu 1984 Stomatolity i microfitolity v stratigraphii dokembria: nadezhdy i realnost (Stromatolites and micrphytolites in Precambrian stratigraphy: hopes and reality); Sovetskaya Geologiya $\mathbf{8}$ $43-54$.

Golovenok V K and Belova M Yu 1993 The microfossils in the cherts from the Riphean deposits of the Turukhansk Uplift; Strat. Geol. Correl. 1 51-61.

Golubic S 1973 Stromatolites, fossils and recent: a case history; In: Biomineralization and Biological Metals Accumulation (eds) Westbroek $\mathrm{P}$ and de Jong EW Reidel, Dordrecht, pp. 313-326.

Golubic S 1976 Organisms that build stromatolites; In: Stromatolites (ed.) Walter M R (Amsterdam: Elsevier) pp. 113-126.

Golubic S, Sergeev V N and Knoll A H 1995 Mesoproterozoic Archaeoellipsoides: akinetes of heterocystous cyanobacteria; Lethaia 28 285-298.

Green J W, Knoll A H, Golubic S and Swett K 1987 Paleobiology of distinctive benthic microfossils from the Upper Proterozoic Limestone - Dolomite "Series" central east Greenland; American Journal of Botany 62 835-852.

Hofmann H J 1974 The stromatolite Archaeozoon acadiense from the Proterozoic Green Head Group of Saint John, New Brunswick; Can. J. Earth Sci. 11 1098-1115.

Hofmann H J 1976 Precambrian microflora, Belcher island, Canada: significance and systematics; J. Paleontol. 50 1040-1073.

Hofmann H J and Schopf J W 1983 Early Proterozoic microfossils; In: "Earth's Earliest Biosphere: It's origin and Evolution" (ed.) Schopf J W (Princeton, New Jersey: Princeton University Press) pp. 321-360.

Hofmann H J and Jackson G D 1991 Shelf facies microfossils from the Uluksan Group (Late Proterozoic) Bylot Supergroup, Baffin Island, Canada; J. Palaeontol. 65 361-382.

Horodyski R J and Donaldson J A 1980 Microfossils from the Middle Proterozoic Dismal Lakes Group, Arctic Canada; Precamb. Res. 11 125-159.

Horodyski R J and Donaldson J A 1983 Distribution and significance of microfossils in cherts of the Middle Proterozoic Dismal Lakes Group, District of Mackenzie, Northwest Territories; Canada. J. Earth Sci. 17 $1166-1173$.

Horodyski R J and Von der Haar S 1975 Recent calcareous stromatolites from Laguna Mormona, Mexico; J. Sedim. Petrol. 45 894-906.

Horodyski R J, Bloesser B and Von der Haar S 1977 Laminated algal mats from a coastal lagoonal, Laguna Mormona, Baja California, Mexico; J. Sedim. Petrol. 47 680-696.

Jankauskas T V 1982 Mikrofossilli Rifeya Yzhnogo Urala (Microfossils of the Riphean of the south Urals) In: "Stratotype of Russian Palaeontology and Palaeomagnetics" (ed.) Keller B M, Nauka, Moscow, pp. 84-120.

Jankauskas T V, Mikhailova N S and German T N 1989 Mikrofossilii dokembrya SSSr (Precambrian microfossils of the USSR), Nauka Leningrad, $190 \mathrm{pp}$.

Kinsman D J and Park R K 1976 Algal belt and coastal sabkha evolution, Trucial Coast, Persian Gulf;
In: Stromatolites: Developments in Sedimentology (ed.) Walter M R (Amsterdam: Elsevier) 20 421-433.

Kirchner O 1898 Schizophyceae; In: Die naturlichen Pflanzenfamilien I; (eds) Engler A and Prantl K, 1a 4-92.

Knoll A H 1982a Microfossils based biostratigraphy of the Precambrian Hecla Hoek sequence, Nordaustlandet, Svalbard; Geol. Mag. 119 269-279.

Knoll A H 1982b Microfossils from the late Precambrian Draken Conglomerate, NY Friesland, Svalbard; J. Paleontol. 56 755-790.

Knoll A H 1985 A paleobiological perspective on sabkha; In: "Ecological Studies" (eds) Friedman and Krumbein W E (Berlin: Springer-Verlag) 53 407-425.

Knoll A H 1996 Archaean and Proterozoic Paleontology; In: "Palynology: Principles and applications" (eds) Jansonios J and Mcgreogor D C, pp. 51-80.

Knoll A H and Golubic S 1979 Anatomy and Taphonomy of a Precambrian algal stromatolite; Precamb. Res. 10 115151.

Knoll A H and Sergeev V N 1995 Taphonomic and Evolutionary changes across the MesoproterozoicNeoproterozoic Transition; N. Jb. Geol. Palaeont. Mh. $195289-302$.

Knoll A H, Sweet K and Burkhandt E 1989 Palaeoenvironment distribution of microfossils and stromatolites in Upper Proterozoic, Backlundtoppen Formation, Spitsbergen; J. Palaeontol. 62 129-145.

Knoll A H, Swett K and Mark J 1991 Paleobiology of a Neoproterozoic tidal flat/lagoonal complex: the Draken Conglomerate Formation, Spitsbergen; J. Paleontology 65 531-570.

Kolosov P N 1982 Verkhnedokembrijskie Paleoalgologicheskie Ostatki Sibirskoj Platformy (Upper Precambrian Palealgological Residues from the Siberian Platform); Nauka, Moscow 94.

Kumar A, Gopalan K and Rajagopalan G 2001 Age of the lower Vindhyan sediments, Central India; Curr. Sci. 81 806-809.

Kumar S 1978 Discovery of microorganisms from the black cherts of the Fawn Limestone, Late Precambrian, Semri Group, Son valley, Mirzapur dist. U.P.; Curr. Sci. 47 461.

Kumar S 1995 Megafossils from the Mesoproterozoic Rohtas Formation (the Vindhyan Supergroup), Katni area, Central India; Precamb. Res. 72 171-184.

Kumar S 2001 Mesoproterozoic megafossil Chuaria-Tawuia association may represent parts of a multicellular plant, Vindhyan Supergroup, Central India; Precamb. Res. 106 187-211.

Kumar S and Srivastava P 1992a Discovery of microfossils from the nonstromatolitic middle Proterozoic Vindhyan Chert, Chitrakut area, U.P.; J. Geol. Soc. India 38 511-515.

Kumar S and Srivastava P 1992b Middle to Late Proterozoic microbiota from the Deoban Limestone, Garwal Himalaya, India; Precamb. Res. 56 291-318.

Kumar S and Srivastava P 1995 Microfossils from the Kheinjua Formation, Mesoproterozoic Semri Group, Newari area, Central India; Precamb. Res. 74 91-117.

Leo R F and Barghoorn E S 1976 Silicification of wood; Bot. Mus. Leafl. Harv. Univ. 2547.

Liu C 1982 Microfossil algae communities from the Wuminshan Formation in Jixian, China and their Geological significance; Bull. Nanjing Univ. (Special issue on algae: algal monograph) 6 121-166.

Liu X, Liu Zhili, Zhang Lun and Xu Xuesi 1984 A study of Late Precambrian microfossil algal community from Suining County, Jiangsu Province; Acta Micropalaeontol. Sinica 1 171-182 (In Chinese with English abstract). 
Lo S C 1980 Microbial fossils from the Lower Yudoma Suite, Earliest Phanerozoic eastern Siberia; Precamb. Res. 13 109-166.

Logan B W, Hoffman P and Gebelin C D 1974 Algal mats, cryptalgal fabrics and structures, Hamelin Pool, Western Australia; Am. Soc. Pteroleum Geologists Mem. 22 140-194.

Luo Q L, Wang F X and Wang Y G 1983 Uppermost Simian and Lowermost Cambrian age microfossils from Qi agzhen-Zhijin county in Guizhou Province; Bull. Tianjin Instt. Geol. Min. Resources 6 23-41.

Maithy P K 1989 Small stromatolites of middle Proterozoic Semri Group, Vindhyan Supergroup from Rohtas, Bihar; Him. Geol. 13 83-86.

Maithy P K and Shukla Manoj 1984 Reappraisal of Fermoria and allied remains from Suket Formation; Palaeobotanist 32 146-152.

Maliva R G, Knoll A H and Siever R 1989 Secular change in chert distribution: a reflection of evolving biological participation in silica cycle; Palaios 4 519-532.

Margulis L, Barghoorn E S, Ashendorf D, Banerjee S, Chase D, Francis S, Giovannoni S and Stolz J 1980 The microbial community in the layered sediments at Laguna Fiueroa, Baja California, Mexico: does it have Precambrian analogues?; Precamb. Res. 11 93-123.

McMenamin D S, Kumar S and Awramic S M 1983 Microbial fossils from the Kheinjua Formation, Middle Proterozoic Semri Group (Lower Vindhyan), Son Valley area, Central India; Precamb. Res. 21 247-271.

Mendelson C V and Schopf J W 1982 Proterozoic microfossils from the Sukhaya Tungusks, Shorikha and Yudoma Formations of Siberian Platform, USSR; J. Palaeontol. $5642-83$.

Milliken K L 1979 The silicified evaporite syndrome - two aspects of silicification history of former evaporite nodules from southern Kentucky and northern Tennessee; J. Sedim. Petrol. 49 245-256.

Moorman M 1974 Microbiota of the Late Proterozoic Hector Formation, Southwestern Alberta, Canada; J. Palaeontol. 48 524-539.

Muir M D 1976 Proterozoic microfossils from the Amelia Dolomite, McArthur Basin, Northern Territory; Alcheringa 1 143-158.

Nägeli C 1849 Gattungen einzelliger Algen, physiologisch und under systematisch bearbeitet; F. Schulthes, Zürich, $139 \mathrm{pp}$.

Oehler D Z 1978 Microflora of the middle Proterozoic Balbirini Dolomite (McArthur Group) of Australia; Alcheringa 2 269-310.

Oehler J H 1977 Microflora of the H Y C Pyritic Shale Member of the Barney Creek Formation (McArthur Group), Middle Proterozoic of northern Australia; Alcheriga 1 $315-349$

Ogurtsova R N and Sergeev V N 1987 The microbiota of Upper Precambrian Chichkanskaya Formation in the Lesser Karatau Region (southern Kazakhistan) Palentologicheskii Zhurnal 2 101-112 (english version).

Playford P E and Cockbain A E 1976 Modern Algal Stromatolites at Hamelin Pool, a hypersaline barred basin in Shark Bay, Western Australia; In: Stromatolites: Developments in Sedimentology (ed.) Walter M R (Amsterdam: Elsevier) 20 389-411.

Prakash Om and Kumar Y 1980 A Report on the systematic geological mapping in parts of Rohtas district, Bihar (FS 75-76/12155/63P/10, P/13) Unpublished GSI Report.

Pjatiletov V G 1988 Mikrofitofossilii pozdnego dokembriya Uchuromajaskogo rajona (Microphytofossils from the late Precambrian of Ucur-Maia region) In: Pozdnij Dokembrij I Rannji Paleozoj Sibiri Rifej $i$ Vend (eds)
Khomentovsky V V and Schenfil Vy, pp. 47-104 Institut Geologii I Geofiziki SO AN SSSR, Novosibirsk.

Rai Vibhuti and Gautam Rajita 1998 New occurrence of carbonaceous megafossils from the Meso to Neoproterozoic horizons of the Vindhyan Supergroup, Kaimur-Katni areas, Madhya Pradesh, India; Geophytology 26 13-25.

Rasmussen B, Bose P K, Sarkar S, Banerjee S, Fletcher I R and McNaughton N J 20021.6 Ga U-Pb Zircon age for Chorhat Sandstone, Lower Vindhyan, India: Possible implications for early evolution of animals; Geology $\mathbf{3 0}$ 103-106.

Ray J S, Martin M W, Veizer J and Bowring S A 2002 U-Pb zircon dating and $\mathrm{Sr}$ isotope systematics of the Vindhyan Supergroup, India; Geology 30 131-134.

Ray J S, Veizer J and Davis W J 2003 C, O, Sr, and Pb isotope systematics of carbonate sequences of the Vindhyan Supergroup, India: age, diagenesis, correlations and implications for global events; Precamb. Res. 121 103-140.

Rippka Rosmarie, Josette Deruelles, Waterbury J B, Michael Herdman and Stanier R Y 1979 Generic assignments, Strain histories and properties of pure cultures of Cyanobacteria; J. Gen. Microbiology 111 1-61.

Sarangi S, Gopalan K and Kumar S $2004 \mathrm{~Pb}-\mathrm{Pb}$ age of earliest megascopic, eukaryotic alga bearing Rohtas Formation, Vindhyan Supergroup, India: implications for Precambrian atmospheric oxygen evolution; Precamb. Res. 132 107-121.

Sarkar A N 1981 Stratigraphy and structure of the Lower Vindhyan rocks of Palamau District, Bihar; Misc. Publ. Geol. Surv. India 50 21-30.

Sarkar S, Banerjee S and Bose P K 1996 Trace fossils in the Mesoproterozoic Koldaha Shale, Central India and their implications; N. Jb. Geol. Palaeont. Mh. 7 425-438.

Schenfil V Yu 1983 Vodorosli v dokembriiskih otlozheniyakh Vostochnoi Sibiri (Algae in the Precambrian deposits of Eastern Siberia); Doklady AN SSSR 269 471-473.

Schopf J W 1968 Microflora of the Bitter Springs Formation, Late Precambrian, Central Australia; J. Paleontol. 42 651-688.

Schopf J W 1992 Atlas of representative Proterozoic microfossils; In: "The Proterozoic Biosphere" (eds) Schopf J W and Klein C (Cambridge: Cambridge University Press) pp. 1055-1118.

Schopf J W and Blacic B M 1971 New microorganisms from the Bitter Springs Formation (Late Precambrian) of the north-central Amadeus Basin, Central Australia; J. Paleontol. 45 925-960.

Schopf J W and Klein C 1992 The Proterozoic Biosphere, Cambridge Univ. Press, 1348 pp.

Seilacher A, Bose P K and Pfluger F 1998 Triploblastic animals more than 1 billion years ago: trace fossils evidence from India; Science 282 80-83.

Seong-Joo L and Golubic S 1998 Multi-trichomous cyanobacterial microfossils from the Mesoproterozoic Gaoyuzhuang Formation, China: Paleoecological and taxonomic implications; Lethaia 31 169-184.

Sergeev V N 1984 Mikrofossilii v okreyemnistikh stolochatikh stromatolitakh verkhego rifeya Turukhanskogo raiona (Microfossils in Upper Riphean silicified columnar stromatolites from the Turukhansk area) Doklady Akademii Nauk SSSR 278 436-439.

Sergeev V N 1992 Okremnennye mikrofossilii dokembrya i kembrya Urala i Sredney Azii (Silicified microfossils from the Precambrian and Cambrian deposited of the southern Ural Mountains and Middle Asia); Nauka, Moscow, 134 pp.

Sergeev V N 1994 Microfossils in cherts from the Middle Riphean (Mesoproterozoic) Avzyan Formation, southern 
Ural Mountains, Russian Federation; Precamb. Res. 65 231-254.

Sergeev V N 2001 Palaeobiology of Neoproterozoic (Upper Riphean), Shorikha and Burovaya silicified microbiotas, Turukhansk Uplift, Siberia; J. Palaeontol. 75 427-448.

Sergeev V N, Knoll A H and Grotzinger J P 1995 Paleobiology of the Mesoproterozoic Billyakh Group, Anabar uplift, Norhern Siberia; Palaeontological Soc. Mem. 39 $1-37$.

Sergeev V N, Knoll A H, Kolosova S P and Kolosov P N 1994 Microfossils in cherts from the Mesoproterozoic Debengda Formation, Olenek Uplift, Northeastern Siberia; Strat. Geol. Correlation 2 23-38.

Sergeev V N, Knoll A H and Petrov P Yu 1997 Paleobiology of the Mesoproterozoic-Neoproterozoic Transition: The Sukhaya Tunguska Formation, Turukhansk Uplift, Siberia; Precamb. Res. 85 201-239.

Sharma M 1993 Contributions to the Palaeobiology of Mesoproterozoic Vindhyan Sediments of India; Unpublished Ph.D. Thesis, Lucknow University; 299 pp.

Sharma M 1996 Microbiolites (stromatolites) from the Mesoproterozoic Salkhan Limestone, Semri Group, Rohtas, Bihar: their systematics and significance; Geol. Soc. India Memoir 36 167-196.

Sharma M 2003 Age of Vindhyans - Palaeobiological Evidence: A Paradigm Shift(?); J. Palaeontol. Soc. India 48 191-214.

Sharma M and Sergeev V N 2004 Genesis of carbonate precipitate patterns and associated microfossils in Mesoproterozoic formations of India and Russia - a comparative study; Precamb. Res. 134 317-347.

Srivastava P 2005 Vindhyan akinetes: an indicator of Mesoproterozoic biospheric evolution; Origins of life and Evolution of Biosphere 35 175-185.

Srivastava P and Kumar S 2003 New microfossils from the Meso-Neoproterozoic Deoban Limestone, Garhwal Lesser Himalaya India; Palaeobotanist 52 13-47.

Stainer R Y, Sistrom W R, Hansen T A, Whitton B A, Castenholz R W, Pfenning N, Gorlenko V N, Kondratieva E N, Eimhjellen K E, Whittenbury R, Gherna R L and Trüper H G 1978 Proposal to place nomenclature of the cyanobacteria (blue green algae) under the rules of International Code of Nomenclature of bacteria; Int. J. Systematic Bacteriology 28 335-336.

Starr R C 1955 A comparative study of Chlorococcum meneghini and other spherical zoospore producing genera of chlorococcales; Indian Uni. Publi. Sci. Ser. 20 (Bloomington: Indiana Univ. Press).

Strother P K, Knoll A H and Barghoorn E S 1983 Microorganisms from the Late Precambrian Narssarssuk Formation, Northwest Greenland; Palaeontology 26 1-32.

Thuret G 1875 Essai de classification des nostocines; Annales des Sciences Naturelles, Paris (Botanique) 6 $372-382$.

Venkatachala B S, Sharma Mukund and Shukla Manoj 1996 Age and Life of the Vindhyans - Facts and Conjectures; Geol. Soc. India Memoir 36 137-165.

Venkatachala B S, Yadav V K and Shukla Manoj 1990 Middle Proterozoic microbiota from Nauhatta Limestone (Vindhyan Supergroup) Rohtasgarh India; Development in Precambrian Geology 8. In: "Precambrian Continental
Crust and Economic Resources" (ed.) Naqvi S M (Amsterdam: Elsevier) pp. 471-478.

Walsby A E 1974 The isolation of gas vesicles from bluegreen algae; Methods Enzymol. 31A 678-686.

Walter M R 1976 Stromatolites; Developments in Sedimentology (Amsterdam: Elsevier) 790 pp.

Wang-Fuxing, Zhang Xuanyang and Guo Ruihuan 1983 The Sinian Microfossils from Jinning, Yunnan, Southwest China; Precamb. Res. 23 133-175.

Waterbury J B and Stainer R Y 1978 Patterns of growth and development in pleurocapasalean cyanobacteria; Microbiological Reviews 42 2-44.

Wettestein F V 1924 Handbuch der Systematischer Botanik; 3rd edn, Franz Deutike Leipzig, Band 11017.

Woese C and Fox G 1977 Phylogenetic structure of prokaryotic domain; Proc. Nat. Acad. Sci. USA 74 5088-5090.

Xu C L 1984 Investigation on the Prokaryotic microfossils from the Gaoyuzhuang Formation, Jixian, North China; Acta Bot. Sinica 26 216-22 (in chinese with english abstract).

Yakschin M S 1990 K voprosu o prirode microstruktur rannerifeiskih plastovyh stromatolitov (Origin of microstructures in the Early Riphean flat-laminated stromatolites ); In "Iskopaemye problematiki SSSR" (The bizarre fossils of the U.S.S.R.) Moscow, Nauka, pp. 5-13.

Yakschin M S 1991 Vodoroslevaya mikrobiota nizhnego rifeya anabarskogo podnyatia (Algal microbiota from the Lower Riphean deposits of Anabar Uplift); Novosibirsk, Nauka, Sibirskoe Otdelenie, 61 pp.

Zhang Pengyuan 1982 Microfossils from the Wumishan Formation of Jixian County; Acta Geologica Sinica 56 34-41.

Zhang Pengyuan and Gu Shuqin 1986 Microfossils from the Wumishan Formation of Jixian System in the Ming Tombs, Beijing, China; Acta Geologica Sinica 60 13-22.

Zhang Pengyuan and Yan Xiaoli 1984 Microfossils from the Gaoyuzhuang Formation in Laishui County, Hebei, China; Acta Geologica Sinica 58 196-204.

Zhang Yun 1981 Proterozoic Stromatolite microflora of the Gaoyuzhuang Formation (Early Sinian: Riphean), Hebei, China; J. Paleontology 55 485-506.

Zhang Yun, Leiming Yin, Xiao Shuhai and Knoll A H 1998 Permineralised fossils from the Terminal Proterozoic Doushantuo Formation, South China; J. Palaeontol 72 1-52.

Zhang Zhongying 1981a Precambrian microfossils from the Sinian of South China; Nature 289 792-793.

Zhang Zhongying 1981b A new Oscillatoriaceae like filamentous microfossils from the Sinian (Late Precambrian) of Western Hubei Province, China; Geol. Mag. 118 201-206.

Zhang Zhongying 1982 Filamentous microfossils from the Doushantuo Formation (Late Sinian) of South China; J. Paleontol. 56 1251-1256.

Zhang Zhongying 1984 Microflora of the late Sinian Doushantuo Formation, Hubei Province, China; In: "Scientific papers on Geology for International Exchange: Prepared for the 27th International Geological Congress" (eds) Xie L and Zhang J, pp. 129-142.

Zhang Zhongying 1986 New material of filamentous fossils cyanophytes from Doushantuo Formation (late Sinian) in the eastern Yangtze Gorge; Sci. Geol. Sinica 1986 30-37. 